\title{
SHERLOCK HOLMES MEETS RUBE GOLDBERG: FIXING THE ENTRY-INTO-FORCE PROVISIONS OF THE COMPREHENSIVE NUCLEAR TEST BAN TREATY
}

\author{
DAVID A. KOPLOW*
}

\begin{abstract}
The Comprehensive Nuclear Test Ban Treaty (CTBT) is widely heralded as the most important international legal instrument for arresting the nuclear arms race and impeding further nuclear proliferation. Concluded in 1996, the treaty has been signed by 183 countries and ratified by 166. But it has not yet entered into force, because of its unique requirement that it not become operational for any state until it has been ratified by all forty-four countries designated in its Annex 2. Thirty-six of those Annex 2 states have ratified, but there is little prospect that all of the other eight (including the United States, China, India, Pakistan, and North Korea) will do so in the foreseeable future. In the meantime, certain parts of the CTBT are being provisionally applied, but other critical aspects are in abeyance, and the world's unrequited demand for a fully effective legal prohibition on nuclear weapons testing has jeopardized the global nuclear security architecture.

This Article proposes a novel work-around, to achieve early implementation of the CTBT. Interested states should negotiate a second treaty, styled as an Implementing Agreement, through which they could promptly effectuate the CTBT among themselves, even if some Annex 2 states remained outside the regime. This approach would free the CTBT from the tyranny of a "veto power" currently held by each of the Annex 2 states, and would allow the treaty to grow organically, building toward eventual

\footnotetext{
Copyright (C) 2017 David A. Koplow

Professor of Law, Georgetown University Law Center. The author gratefully thanks the following experts, colleagues, and friends for their extraordinary comments, insights, and suggestions in the preparation of this manuscript: David A. Balton, Michael R. Cannon, Pierce S. Corden, Robert E. Dalton, James D. Fry, Brenna Gautam, Collmann Griffin, Duncan B. Hollis, Peter Hulsroj, Raymond Jeanloz, David S. Jonas, Daniel H. Joyner, Jenifer Mackby, John Norton Moore, Sean D. Murphy, Jonathan G. Odom, Thomas R. Pickering, J. Ashley Roach, Philip G. Schrag, Abraham J. Shanedling, and David P. Stewart. In addition, Mabel Shaw, Kasie Durkit, Ron Havas, and James Kachadoorian
} provided invaluable research assistance and support.
\end{abstract}


universal acceptance by entering into force now for a sizeable coalition of the willing - as other important treaties have traditionally done.

The legal mechanism for creating such an Implementing Agreement is unusual and cumbersome, but it follows an important international law precedent. The 1982 Law of the Sea Convention achieved widespread acceptance, but it, too, required substantial modification before its entry into force. There, the participating states successfully fashioned a 1994 Implementing Agreement to revise important elements. That document provides a useful template for the CTBT to emulate.

This Article offers a draft of a CTBT Implementing Agreement, explaining how its waiver provisions would operate and how it would provide interested states a variety of alternative mechanisms for establishing a prompt, durable, and legally binding test ban regime.

\section{TABLE OF CONTENTS}

ABSTRACT 1

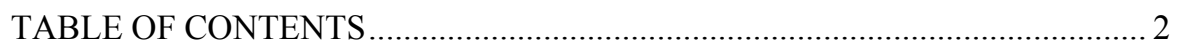

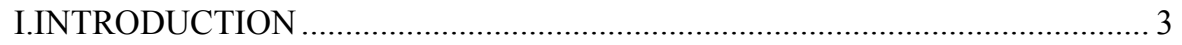

II.THE PROBLEM: CTBT IS CAUGHT IN A QUAGMIRE............................... 5

A. The Importance of CTBT ............................................................... 5

1. CTBT and NPT .................................................................. 7

2. History of Test Bans ...................................................... 8

B. The Stagnation of CTBT …........................................................... 10

1. Entry Into Force Provisions …................................................. 11

2. U.S. Ratification Efforts .............................................................. 15

3. Verification Debates .................................................................. 17

4. Provisional Application of the CTBT …..................................... 18

5. Failed Attempts to Square the Circle .......................................... 22

III.THE WORK-AROUND: AN IMPLEMENTING AGREEMENT ................... 24

A. Manageable Entry into Force Provisions …...................................... 24

B. Altering a Treaty Text .................................................................... 28

C. The Proposed Implementing Agreement............................................ 31

D. The Law of the Sea Convention Precedent ....................................... 35

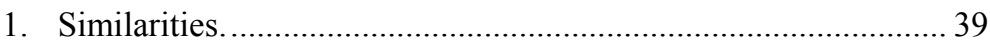

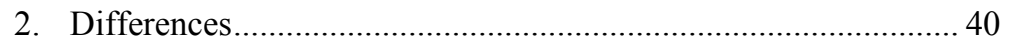

E. Other Precedents .................................................................................. 43

IV.THE PROPOSED TEXT OF THE CTBT IMPLEMENTING AGREEMENT 45

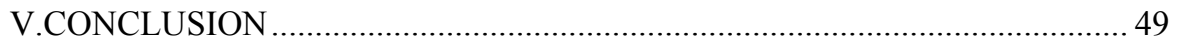




\section{INTRODUCTION}

The Comprehensive Nuclear Test Ban Treaty ${ }^{1}$ (CTBT) - the single most important arms control instrument restricting both nuclear proliferation and the arms race-is in deep trouble. It was opened for signature on September 24, 1996, has been signed by 183 countries and ratified by 166 , but it has still not entered into force, and there is no prospect that it will become legally effective in the foreseeable future.

Much of the CTBT's bureaucratic infrastructure is already in place and operational, on a provisional basis, but some key elements are held in abeyance until the treaty's formal entry into force, and robust international support for even the existing tentative institutions and arrangements may not be sustainable indefinitely.

Moreover, the vulnerability extends beyond this single treaty. The CTBT is widely considered to constitute the most essential linchpin for the 1968 Nuclear Non-Proliferation Treaty ${ }^{2}$ (NPT), the indispensable bulwark against further dissemination of nuclear weapons and the associated materials, equipment, and technology. If the CTBT continues to falter, the enduring fidelity of the NPT's 191 parties will be called into question, too.

The critical legal problem for the CTBT resides in its peculiar-indeed, unique and bizarre provisions regulating its entry into force. Under article XIV, the obligation to refrain from explosive testing of nuclear weapons will not become mandatory for any state until the treaty has been ratified by all forty-four states designated by name in the treaty's Annex 2. This roster ranges from Algeria to Zaire, and includes persistent outlier states such as North Korea, India, and Pakistan, which have exhibited no inclination to join. To date, thirty-six of the Annex 2 states have ratified, but the United States, China, and Israel, among others, have not done so - and even if some did, the remaining hurdles might render the prospect of entry into force illusory.

Numerous international efforts by states, practitioners, and scholars alike, adopting widely varying political and legal strategies, have been floated for reconciling the urgent need for operationalizing the CTBT with its incommodious article XIV, but none have been availing. This Article therefore proffers another kind of approach.

The essential novel proposal in this Article is to negotiate and conclude a new international instrument-here, styled as an Implementing

1. Comprehensive Nuclear-Test-Ban Treaty, Sept. 10, 1996, S. TREATY Doc. No. 105-28, 35 I.L.M. 1439 (not yet in force) [hereinafter CTBT].

2. Treaty on the Non-Proliferation of Nuclear Weapons, July 1, 1968, 21 U.S.T. 483, 729 U.N.T.S. 169 [hereinafter Non-Proliferation Treaty or NPT]. 
Agreement - that would incorporate by reference most of the text of the CTBT but graft on a new provision empowering each state to unilaterally waive for itself the rigid entry into force standards of article XIV. This unorthodox process would enable the treaty to become effective promptly for individual members of a coalition of the willing, even while some Annex 2 holdouts remained outside the regime. Importantly, this Implementing Agreement cannot be structured as a formal amendment to the CTBT because, in Catch-22 fashion, until the CTBT has entered into force, its article VII procedures for adopting and effectuating amendments are not functional either. The conundrum of how to alter the text of a treaty that has been painstakingly negotiated, signed, and ratified by so many states, but has not yet entered into force, has not been resolved or even routinely addressed in international law, but confronting this legal and political puzzle may now provide the best hope for the CTBT and the global security benefits it promises.

The device of a semi-freestanding Implementing Agreement is admittedly cumbersome - some might liken it to a Rube Goldberg invention, in which an extremely elaborate structure with multiple moving parts is laboriously crafted in order to perform an ostensibly simple function. ${ }^{3}$ But this approach has been successfully implemented regarding one other important, highly-visible and widely-accepted treaty in a very different milieu: the 1982 Law of the Sea Convention. ${ }^{4}$ There, the particularly problematic provisions of Part XI (regulating the mining of the deep sea bed) were altered in major ways twelve years later, after the treaty had already been ratified by dozens of countries, but before it had entered into force. The execution of that 1994 precedent cannot prove the desirability of adopting a similar strategy for CTBT, but it does at least establish the legal availability of the concept, and illustrate how such a work-around might function.

To make the case for this proposition, this Article is organized as follows. After this Introduction, Part II presents the CTBT's current quagmire. It highlights both the importance of this treaty (noting its key goals and provisions, its historical evolution, and its intimate connection to the NPT) and the current political dilemmas impeding its entry into force (exploring the text and rationale of article XIV, the saga of the U.S. Senate's negative consideration of the treaty, and the current (limited and perhaps fragile) "provisional application" of the CTBT).

3. See About Rube, RUBEGOLDBERG.COM, https://www.rubegoldberg.com/about/ (last visited Jan. 27, 2017).

4. Convention on the Law of the Sea, Dec. 10, 1982, 1833 U.N.T.S. 3, 21 I.L.M. 1261 (1982) [hereinafter LoSC]. 
Part III then addresses the proposed solution, in the form of an Implementing Agreement styled after that of the Law of the Sea Convention. This discussion explains how the waiver provision would operate, and how the mechanism would be designed to restore to states their traditional freedom of action, enabling a return to "normal" international politics, unconstrained by an overly-restrictive treaty text. It also compares and contrasts my proposed bespoke CTBT Implementing Agreement with the earlier Law of the Sea Convention model.

Part IV presents a skeletal draft text of the proposed CTBT Implementing Agreement. It illustrates the key points, highlights the prominent options, and includes annotations that identify various drafting choices. The draft text is short, but it includes both a waiver provision (enabling states to dispense with the rigidity of Annex 2) and a mechanism for expedited entry into force. The draft is not submitted as a ready-to-sign instrument, but it does at least serve to focus the discussion in more concrete terms.

Finally, Part V offers conclusions, the key element of which is the frank acknowledgment that the better option, overall, would be for the forty-four Annex 2 countries to proceed directly with prompt ratification and implementation of the CTBT; going through the "front door" in making the treaty is always preferable. But if, due to strident domestic political opposition in the United States and elsewhere, that favored course is unavailable, consideration must be given to audacious work-arounds, even if they are cumbersome and unwieldy.

\section{THE PROBLEM: CTBT IS CAUGHT IN A QUAGMIRE}

This Part addresses two key background elements. First, it explains what is at stake here - why the world should care enough about the CTBT to undertake extreme machinations in support of it. Second, it describes the treaty's current plight - how it has gotten ensnared by a perverse entry-intoforce provision, and how its current provisional application, for all its value, remains an inadequate substitute for a fully operational treaty.

\section{A. The Importance of CTBT}

The key provision of the CTBT is stated in disarmingly simple language in its article I: each party "undertakes not to carry out any nuclear weapon test explosion or any other nuclear explosion, and to prohibit and prevent any such nuclear explosion at any place under its jurisdiction or control." ${ }^{5}$ It

5. CTBT, supra note 1, art. I.1. The reference to "any other nuclear explosion" is meant to embrace so-called nuclear explosions for peaceful purposes, such as those that might be undertaken for 
therefore constitutes a permanent, global, legally-binding abolition of nuclear weapon tests.

President Bill Clinton rightly labeled CTBT as "the longest-sought, hardest-fought prize in the history of arms control" - and neither the seeking nor the fighting has abated yet. Although the treaty does not impose any limitations on the numbers of nuclear weapons that states may lawfully manufacture, possess or deploy_ - it aims to "ban the bang," rather than ban the bomb-it pursues an even more important long-term objective, by restricting qualitative improvements in the devices. By blocking states from conducting developmental or proof testing of new weapons, CTBT seeks to impede the proliferation of nuclear weapons to additional states (based on the proposition that countries will be reluctant to invest in complex and technologically sophisticated weapons that they cannot fully certify as functional). At the same time, the treaty interdicts the further refinement and elaboration of the arsenals of states that have already established their nuclear weapons capabilities (again, through the hypothesis that a cautious military establishment would hesitate to rely upon any further expansions of its technology envelope, in the absence of thorough testing). ${ }^{7}$

CTBT advocates concede that this strategy is not iron-clad: a risk-prone state might calculate that it could achieve adequate confidence in a new nuclear weapon design even without explosive testing. But, in practice, states do insist upon thorough testing of new weapons, including nuclear weapons, prior to committing to them-and on the occasions when the traditional testing routines have been foreshortened, disappointingly poor performance has been common. ${ }^{8}$

civil engineering operations (e.g., to excavate an underground chamber or to re-route a river), rather than for the purpose of developing nuclear weapons. See Peaceful Nuclear Explosions, COMPREHENSIVE TEST BAN TREATY ORG. PREP. COMM'N, https://www.ctbto.org/nuclear-testing/history-of-nucleartesting/peaceful-nuclear-explosions/ (last visited Jan. 27, 2017).

6. Bill Clinton, President, Remarks by President Bill Clinton to the $52^{\text {nd }}$ Session of the United Nations General Assembly, THE WhIte House (Sept. 22, 1997), https://clinton4.nara.gov/WH/New/html/19970922-20823.html.

7. JAPP RAMAKER, JeNNIFER MACKBy, PETER D. MARShall \& ROBERT GeIL, The FinAL TEST: A History of the COMPREHENSIVE Nuclear-Test-BAn TREATy NegOtiations 55-57 (2003) (stressing the treaty negotiators' focus on the goals of non-proliferation and arms control); Don Mackay, The Testing of Nuclear Weapons Under International Law, in NUCLEAR WEAPONS UNDER INTERNATIONAL LAW 292 (Gro Nystuen et al. eds., 2014); OLA DAHLMAN, SVEIN MYKKELTVEIT \& HEIN HaAk, Nuclear Test Ban: Converting Political Visions to Reality 14-17 (2009); Daryl G. Kimball, The Enduring Nonproliferation Value of the Comprehensive Nuclear-Test-Ban Treaty, 23 NonProliferation Review, nos. 3-4, 397, 400-03 (2016); NATIONAL ACADEMy of Science, The

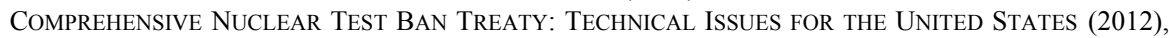
https://www.nap.edu/catalog/12849/the-comprehensive-nuclear-test-ban-treaty-technical-issues-for-the.

8. J. Michael Gilmore, History of U.S. Weapons Proves Value of Realistic Operational Testing, NAtional Defense (January 2015); Pierce S. Corden, Historical Context and Steps to Implement the 
Since July 16, 1945, the United States has conducted some 1032 nuclear weapons explosions - about as many as the rest of the world combined. The "box score" for other states shows the following number of events and the date of the first test by: Russia (715 tests, starting on August 29, 1949); the United Kingdom (45 tests, October 3, 1952); France (210 tests, February 13, 1960); China (45 tests, October 16, 1964); India (3 tests, May 18, 1974); Pakistan (2 tests, May 28, 1998); and North Korea (5 tests, October 9, 2006). ${ }^{9}$

\section{CTBT and NPT.}

This section addresses the intimate linkage between two critical nuclear arms control treaties, in order to demonstrate that the stakes regarding CTBT keep increasing. As the United States and Russia have drawn down their stockpiles of nuclear weapons-from a combined inventory of over 60,000 weapons in 1986 to fewer than 10,000 today - the reliability of the remaining force becomes even more pertinent. ${ }^{10}$ In parallel, as arms controllers contemplate the prospect of still more ambitious constraints - leading, some visionaries stress, to the objectives of reducing the saliency of nuclear weapons in international affairs and ultimately to eliminating nuclear weapons entirely - a viable test ban regime becomes even more essential. ${ }^{11}$

Indeed, many prominent international voices insist that CTBT is already long overdue. The linkage to the NPT is undeniable - a permanent,

CTBT, in BANNING the BANG OR THE Bomb? Negotiating the Nuclear Test BAN Regime 17, 30 (Mordechai Melamud et al. eds., 2014); P. TERRENCE HOPMANN, The Verification Debate and Its Effects on the Negotiation Process, in BANning the BANG OR the Bomb? Negotiating the Nuclear Test BAN REGIME 32, 32-35 (Mordechai Melamud et al. eds., 2014). As an illustration of the limits of the test ban theory of arms control, Israel is widely acknowledged to possess a substantial nuclear weapons arsenal, but has never been proven to have conducted an explosive test. See Arms Control and Proliferation Profile: Israel, ARMS CONTROL ASS'N, https:/www.armscontrol.org/factsheets/ israelprofile (last updated May 2017).

9. Nuclear Testing 1945 - Today, COMPREHENSIVE TeSt BAN TREATY ORG. PreParatory COMM'N, https://www.ctbto.org/nuclear-testing/history-of-nuclear-testing/nuclear-testing-1945-today/ (last visited Jan. 27, 2017); World Overview, COMPREHENSIVE TeST BAN TREATY ORG. PREPARATORY COMM'N, https://www.ctbto.org/nuclear-testing/history-of-nuclear-testing/world-overview/ (last visited Jan. 27, 2017); DAHLMAN ET AL., supra note 7, at 2-8. Note that there are some inconsistencies in the reporting of nuclear testing data, due to uncertainties about the number of separate devices detonated in each test and other factors.

10. Nuclear Notebook: Nuclear Arsenals of the World, BULLETIN ATOMIC SCIENTISTS, http://thebulletin.org/nuclear-notebook-multimedia (last visited Jan. 27, 2017); Hans M. Kristensen \& Robert S. Norris, Russian Nuclear Forces, 2016, Bulletin ATOMIC SCIENTISTS (May 3, 2016), http://thebulletin.org/2016/may/russian-nuclear-forces-20169394; Hans M. Kristensen \& Robert S. Norris, United States Nuclear Forces, 2016, Bulletin Atomic Scientists (Mar. 3, 2016), http://thebulletin.org/2016/march/united-states-nuclear-forces-20169232.

11. Philip TAubman, The Partnership: Five Cold Warriors AND Their Quest to Ban the Bomb (2011); GetTing to Zero: The PATH to Nuclear DisArmament (Catherine McArdle Kelleher \& Judith Reppy eds., 2011); Glob. Zero Comm'N, Global Zero Action Plan (Feb. 2010), http://www.globalzero.org/files/gzap_6.0.pdf. 
global, complete test ban is routinely cited as the critical quid pro quo in return for the promise by 186 of the NPT parties to abjure forever their erstwhile right to develop nuclear weapons of their own. ${ }^{12}$ Article VI of the NPT commits parties to pursue in good faith negotiations on "effective measures" of arms control, ${ }^{13}$ and for many impatient partisans, that phrase is code for achieving a CTBT. The NPT regime has revealed deep fissures of its own, and until the promise of a test ban is redeemed, the stability of the entire post-World War II nuclear security structure lies in peril. ${ }^{14}$

\section{History of Test Bans}

CTBT has been a hardy perennial on the international agenda of arms control since the late 1940s and 1950s ${ }^{15}$ but the world has pursued the treaty in an erratic stepwise fashion. One precursor was the 1963 Limited Test Ban Treaty ${ }^{16}$ (LTBT), a multilateral instrument through which states agreed to

12. RAMAKER, supra note 7, at 7-8; CORDEN, supra note 7, at 22, 25; THOMAS GRAHAM JR. \& DAMIEN J. LAVERA, CORNERSTONES OF SECURITY: ARMS CONTROL TREATIES IN THE NuClEAR ERA 98, 106 (2003); William Epstein, The Non-Proliferation Treaty and the Review Conferences, in 2 ENCYClOPEDIA OF ARMS CONTROL AND DisARMAMENT 855, 862-68 (Richard D. Burns ed., 1993); Taous Feroukhi, Two Treaties Closely Intertwined, CTBTO SPECTRUM, Apr. 2015, at 10, https://www.ctbto.org/fileadmin/user_upload/pdf/Spectrum/2015/Spectrum_23_p10.pdf. The NPT establishes two classes of parties: the "nuclear weapon states" (NWS) (who had already developed nuclear weapons, and would be allowed to retain them) and the "non-nuclear weapon states" (NNWS) (who agreed not to acquire nuclear weapons).

13. NPT, supra note 2, art. VI (each party "undertakes to pursue negotiations in good faith on effective measures relating to cessation of the nuclear arms race at an early date and to nuclear disarmament"). A ban on nuclear weapons testing is the only arms control proposal specifically identified in the NPT's preamble. Id. at preamble 10.

14. RAMAKER, supra note 7, at 12; Daniel H. Joyner, The Legal Meaning and Implications of Article VI of the Non-Proliferation Treaty, in NUCLEAR WEAPONS UNDER INTERNATIONAL LAW 397 (Gro Nystuen, Stuart Casey-Maslen \& Annie G. Bersagel eds., 2014); GRAHAM \& LAVERA, supra note 12, at 1376 (referring to CTBT as "the litmus test" for judging whether the states that possess nuclear weapons were fulfilling their obligations under art. VI of the NPT); Epstein, supra note 12; MARY BETH D. Nikitin, Cong. Research Serv., RL33548, Comprehensive Nuclear-Test-Ban Treaty: BACKGROUND AND CURRENT DEVElopMENTS, 22-26 (2016); Fumio Kishida, Kairat Abdrakhmanov \& Lassina Zerbo, Joint Appeal, May 2, 2017, available at https://www.ctbto.org/ fileadmin/user_upload/statements/2017/02052017_CTBTO_Japan_Kazakhstan_JointAppeal.pdf.

15. RAMAKER, supra note 7, at 1-5; REBECCA JOHNSON, UNFINISHED BUSINESS: THE NEgOtiation OF THE CTBT AND THE END OF NuClEAR TESTING, UNIDIR/2009/2 (2009); HopmanN, supra note 8, at 32, 38-46; GRAHAM \& LAVERA, supra note 12, at 1375; Benjamin S. Loeb, Test Ban Proposals and Agreements: The 1950s to the Present, in 2 ENCYCLOPEDIA OF ARMS CONTROL AND DISARMAMENT 827 (Richard D. Burns ed., 1993); 1945-54: Early Efforts to Restrain Nuclear Testing, Comprehensive Test BAn Treaty Org. PreP. Comm'N, https://www.ctbto.org/the-treaty/history1945-1993/1945-54-early-efforts-to-restrain-nuclear-testing/ (last visited Jan. 23, 2017); NIKITIN, supra note 14, at 1-2; Jenifer Mackby, Still Seeking, Still Fighting, 23 NonProlifERATION REVIEW, nos. 3-4, 261 (2016) [hereinafter Mackby Still Seeking]

16. Treaty Banning Nuclear Weapon Tests in the Atmosphere, in Outer Space and Under Water, Aug. 5, 1963, 14 U.S.T. 1313 [hereinafter Limited Test Ban Treaty or LTBT]. This treaty is also sometimes cited as the Partial Test Ban Treaty. 
prohibit nuclear test explosions in the atmosphere, under water, and in outer space, confining them to deep underground chambers. ${ }^{17}$ The LTBT staunched the production of airborne radioactivity from explosions, serving as a public health and environmental protection measure as well as a partial barrier to the development of new weapons. ${ }^{18}$ Two bilateral U.S.-U.S.S.R. increments followed: the 1974 Threshold Test Ban Treaty ${ }^{19}$ and the 1976 Peaceful Nuclear Explosions Treaty ${ }^{20}$ (each supplemented by extensive protocols in 1990 to enhance verification of compliance). ${ }^{21}$ These confined the size of the permitted underground nuclear events, contributing to limit the superpowers' process of inventing and perfecting new weapons. ${ }^{22}$ In addition, a series of regional treaties has created "nuclear weapon free zones" covering much of the world; these include prohibitions on the conduct of nuclear weapon tests in the defined zones. ${ }^{23}$

Another, possibly even more important, kind of inhibition has arisen from the exchange of non-legally-binding national declarations of "moratoria" against the conduct of nuclear tests. These unilateral but parallel exercises of restraint have emerged in two separate eras. First, between 1958 and 1961, the United States, the Soviet Union, and the United Kingdom reciprocally refrained from conducting explosive tests, relying on remote monitoring of each other's activities, during the pendency of negotiations on what became the LTBT. $^{24}$

The second, current moratorium period has proven to be far more widespread and long-lasting, even though it, too, is not legally compulsory. Russia, for example, has voluntarily not conducted a nuclear explosion since October 24, 1990; the United States has refrained since September 23, 1992. Other nuclear powers have eschewed testing, too: the United Kingdom (since

17. Id. at art. I. See RAMAKER, supra note 7, at 6-7; HOPMANN, supra note 8, at 41-46; GRAHAM \& LAVERA, supra note 12, at 29-31; Loeb, supra note 15, at 830-35; JOHNSON, supra note 15, at 13-16.

18. RAMAKER, supra note 7, at 7; Mackay, supra note 7, at 294-96; JOHNSON, supra note 15, at 16; The MAKing Of THE Limited Test Ban TREATY, 1959-1963 (William Burr \& Hector L. Montford eds., 2003), http://nsarchive.gwu.edu/NSAEBB/NSAEBB94/.

19. Treaty on the Limitation of Underground Nuclear Weapon Tests, U.S.-U.S.S.R., July 3, 1974, 1714 U.N.T.S. 217

20. Treaty on Underground Nuclear Explosions for Peaceful Purposes, U.S.-U.S.S.R., May 28, 1976, 1714 U.N.T.S. 432.

21. See GRAHAM \& LAVERA, supra note 12, at 374, 376, 439.

22. RAMAKER, supra note 7, at 9, 11; GRAHAM \& LAVERA, supra note 12, at 372, 434; Loeb, supra note 15, at 836-37, 839-41; JOHNSON, supra note 15, at 20. Under these treaties, underground nuclear explosions are confined to less than 150 kilotons yield.

23. See GrAHAM \& LAVERA, supra note 12, at 41-97.

24. Treaty Banning Nuclear Weapon Tests in the Atmosphere, in Outer Space, and Under Water, U.S. DeP'T State, Bureau ARMs Control, Verification and Compliance, http://www.state.gov/t/avc/trty/199116.htm; RAMAKER, supra note 7, at 3-6; Loeb, supra note 15, at 829-31. 
November 26, 1991), France (since January 27, 1996), China (since July 29 , 1996), India (since May 13, 1998), and Pakistan (since May 30, 1998). ${ }^{25}$ Only North Korea has tested during the $21^{\text {st }}$ century, events that prompted robust condemnation and sanctions from the U.N. Security Council. ${ }^{26}$

As welcome as this pattern of national self-restraint is, and as valuable as the prior string of treaties may be, they do not accrete into an operational CTBT. ${ }^{27}$ Until that treaty comes into force, the proscription against the development and dissemination of nuclear weapons is still inchoate and incomplete. ${ }^{28}$ And as discussed in the next section, the prospects for reaching that legal watershed are remote, at best.

\section{B. The Stagnation of CTBT}

By many measures, the CTBT has achieved stunning success. The dogged pursuit of universality has brought 183 signatories into the foldwith a few conspicuous exceptions noted below, the thirteen non-signatories are largely peripheral to international affairs and preoccupied with their own internal disruptions. Some 166 states have already deposited instruments of ratification, with strong representation from every continent, bloc, and interest group, and including three states that have long possessed nuclear weapons (France, Russia, and the UK). Admittedly, much of the momentum toward affiliation has abated; the most recent signature (Niue) came on April 9, 2012, and only two states (Swaziland and Myanmar) have ratified within

25. Nuclear Testing 1945 - Today, Comprehensive Test BAn TREATy Org. PreP. Comm'N, https://www.ctbto.org/nuclear-testing/history-of-nuclear-testing/nuclear-testing-1945-today/; NIKITIN, supra note 14, at 1-14; JoHNSON, supra note 15, at 40-46.

26. See S.C. Res. 2270 (Mar. 2, 2016) (condemning North Korea's nuclear weapons test and imposing stringent economic sanctions); S.C. Res. 2094 (Mar. 7, 2013); S.C. Res. 1874 (June 12, 2009); Leon V. Sigal, Getting What We Need with North Korea, 46 ARms ConTrol TodAY 8, Apr. 2016; NiKiTIN, supra note 14, at 15-21.

27. See also Pakistan Offers Nuclear Non-Testing Agreement to India, INDIAN EXPRESS (Aug. 16, 2016), http://indianexpress.com/article/india/india-news-india/pakistan-offers-nuclear-non-testingagreement-to-india-2979122/ (describing proposal by Pakistan to India to conclude a legally-binding bilateral test ban treaty); Beyza Unal, Patricia Lewis, and Susan Aghlani, The Humanitarian Impacts of Nuclear Testing: Regional Responses and Mitigation Measures, Chatham House, May 8, 2017, https:/www.chathamhouse.org/publication/humanitarian-impacts-nuclear-testing-regional-responsesand-mitigation-measures (emphasizing the adverse public health and environmental effects of nuclear weapons testing, and calling for entry into force of the CTBT).

28. Note that under the NPT, most parties are already indirectly prohibited from testing nuclear weapons, even prior to entry into force of the CTBT, because they have agreed not to receive, manufacture or acquire nuclear weapons; possession or control of a nuclear weapon would be a precursor to conducting a test explosion. NPT, supra note 2, art. II. 
the past two years - but much of that slowdown may be attributable to the simple fact that there are not many strays left to absorb. ${ }^{29}$

But upon closer inspection, the portrait is not so salutary. As explored infra, the most relevant membership criterion is the participation by the forty-four states identified in Annex 2 of the treaty; their affiliation is necessary for the CTBT to enter into force for anyone. Among that select clique, forty-one have signed (not including India, North Korea, and Pakistan) and thirty-six have ratified (excluding China, Egypt, Iran, Israel, and the United States, in addition to the aforementioned three states). No Annex 2 state has signed the treaty since Bangladesh on October 24, 1996, and none has ratified since Indonesia on February 6, 2012. ${ }^{30}$

\section{Entry Into Force Provisions}

The spare language of article XIV.1 has created this profound anomaly: "This Treaty shall enter into force 180 days after the date of deposit of the instruments of ratification by all States listed in Annex 2 to this Treaty, but in no case earlier than two years after its opening for signature." ${ }^{31}$ Annex 2 then contains the names of the forty-four states that were active members of the Conference on Disarmament (a United Nations affiliate, charged with primary responsibility for negotiating instruments such as the $\mathrm{CTBT}^{32}$ ) and that were contemporaneously identified by the International Atomic Energy Agency $^{33}$ (IAEA) as possessing nuclear power reactors or nuclear research reactors. ${ }^{34}$ That august group does include most of the countries that are, in some sense, nuclear-capable, and whose participation in a test ban regime would be especially desirable. But to condition the entry into force of the treaty for anyone upon the unanimous assent by such a large and diverse group is both largely unprecedented and highly unfortunate. ${ }^{35}$

29. Status of Signature and Ratification, Comprehensive TeSt BAN Treaty Org. Prep. COMM'N, https://www.ctbto.org/the-treaty/status-of-signature-and-ratification/ (last visited Jan. 27, 2017).

30. Id.

31. CTBT, supra note 1, art. XIV.1.

32. See An Introduction to the Conference, THE U.N. OfFICE AT GENEVA, http://www.unog.ch/80256EE600585943/(httpPages)/BF18ABFEFE5D344DC1256F3100311CE9?Ope nDocument (presenting the history, operations and membership of the Conference on Disarmament).

33. See History, INT'L ATOMIC ENERGY AGENCY, https://www.iaea.org/ (last visited Jan. 23, 2017) (describing the operations of IAEA).

34. CTBT, supra note 1, at Annex 2 to the Treaty.

35. Id. (providing the: "List of States members of the Conference on Disarmament as at 18 June 1996 which formally participated in the work of the 1996 session of the Conference and which appear in Table 1 of the International Atomic Energy Agency's April 1996 edition of 'Nuclear Power Reactors in the World,' and of States members of the Conference on Disarmament as at 18 June 1996 which formally participated in the work of the 1996 session of the Conference and which appear in Table 1 of the 
The United States was the first country to sign the CTBT, ${ }^{36}$ but as elaborated infra, it has not yet ratified. Some observers have speculated that U.S. ratification, whenever it occurs, could prompt a modest cascade among other Annex 2 holdouts, with $\mathrm{China}^{37}$ and perhaps Israel $^{38}$ joining shortly thereafter. But even if that contingency transpired, it would require additional regional political seismic shifts to secure ratification by India and Pakistan, and the political permutations would have to play out in even more unexpected ways to imagine North Korea and Iran associating themselves with the CTBT. ${ }^{39}$ So while it is possible that the treaty will inch forward with additional signatures and ratifications in the years to come, it is hard to foresee entry into force, even if the United States were at some point in the future to ratify with a gusto that might sweep some others along, too.

Why was the treaty crafted in this peculiar way-why did the negotiators deliberately insert what might be called a "non-entry-into-force"

International Atomic Energy Agency's December 1995 edition of 'Nuclear Research Reactors in the World': Algeria, Argentina, Australia, Austria, Bangladesh, Belgium, Brazil, Bulgaria, Canada, Chile, China, Colombia, Democratic People's Republic of Korea, Egypt, Finland, France, Germany, Hungary, India, Indonesia, Iran (Islamic Republic of), Israel, Italy, Japan, Mexico, Netherlands, Norway, Pakistan, Peru, Poland, Romania, Republic of Korea, Russian Federation, Slovakia, South Africa, Spain, Sweden, Switzerland, Turkey, Ukraine, United Kingdom of Great Britain and Northern Ireland, United States of America, Viet Nam, Zaire.")

36. See 1996: CTBT: A Long-Sought Success, COMPREhEnsive TeSt BAN TrEATy Org. PreP. COMM'N, https://www.ctbto.org/the-treaty/1993-1996-treaty-negotiations/1996-ctbt-a-long-soughtsuccess/ (last visited Jan. 23, 2017).

37. Kevin Rudd, A U.S.-China Roadmap for CTBT Ratification, CTBTO SPECTRUM, Apr. 2015, at 9; Rakesh Sood, Why the CTBT Remains an Elusive Goal, OBSERVER RES. FounD., Oct. 2016, at 1, http://cf.orfonline.org/wp-content/uploads/2016/10/ORF_Issue_Brief_161_on_CTBT.pdf.

38. Israel Backs Nuclear Test Ban Treaty - With No Timeframe for Ratification, DEUTSCHE WELLE (June 20, 2016), http://www.dw.com/en/israel-backs-nuclear-test-ban-treaty-with-no-timeframefor-ratification/a-19343675 (reporting Israeli government support for the CTBT); Bernard Sitt, What Does the Future Hold for the CTBT?, 89 CESIM 1 (2014), http://www.cesim.fr/documents/onp/eng/89.pdf (anticipating that U.S. ratification of the CTBT would create a "virtuous circle" with other states soon joining, too); NIKITIN, supra note 14, at 13-14 (assessing reported conditions for Israeli ratification of CTBT); Massimiliano Moretti, The Past, Present, and Future of the CTBT(O): A Conversation with the Executive Secretary, 23 NONPROLIFERATION REVIEW, nos. 3-4, 253, 255-56 (speculating about a "domino effect" of countries' ratifications, and reporting that Israel's ratification of the CTBT is a "matter of 'when' not 'if"').

39. Sood, supra note 37 , at 5-6 (discussing the difficulty of obtaining ratification by India and Pakistan); Tariq Rauf, 'Unfinished Business' on the Twentieth Anniversary of the Comprehensive Nuclear-Test-Ban Treaty (CTBT), SIPRI (Sept. 26, 2016), https://www.sipri.org/commentary/topicalbackgrounder/2016/unfinished-business-twentieth-anniversary-comprehensive-nuclear-test-ban-treaty (reporting that the prospects for CTBT entry into force "remain dim"); Jenifer Mackby, Nonproliferation Verification and the Nuclear Test Ban Treaty, 34 FORDHAM INT'L L.J. 697, 727-31 (2011) (discussing treaty prospects in the states that have not yet ratified) [hereinafter, Mackby Nonproliferation Verification]; NIKITIN, supra note 14, at 10-14; Kimball, supra note 7, at 404 (reporting a senior North Korean official commenting favorably about the "great contribution to world peace and stability" that CTBT's entry into force would provide). 
provision into article XIV? Jaap Ramaker, who served as chair of the CTBT negotiations in 1996, has emphasized that the deliberations over the treaty's entry into force provisions became "the hottest item" 40 for the delegations, other than the controversy over the scope of the treaty's basic obligations, and that article XIV turned out to be "the most contentious issue" 41 in the negotiations' end game.

The ambassadors needed to balance several competing interests in this context. ${ }^{42}$ First, one widely-accepted principle was to require that when the treaty eventually entered into force, it would affect a large number of countries simultaneously, so each state could be confident that it would not be asymmetrically constrained. That is, the CTBT should not finally deprive any state of its right to exercise a conceivably militarily-and politicallyvaluable nuclear weapons option unless its potential adversaries would be identically obligated. In a complex and heterogeneous world, where one state's nuclear arsenal could plausibly threaten many neighbors (and nonneighbors), the global threat matrix seemed tightly interwoven. ${ }^{43}$

A second, related criterion was to ensure that the treaty would embrace certain key states right from the start-and opinions differed as to which specific states were sufficiently "key" that their immediate participation should be required. Many participants concluded that the roster would have to include at least the five permanent members of the U.N. Security Council (China, France, Russia, the United Kingdom, and the United States-who are, not just coincidentally, also the states that were recognized under the Nuclear Non-Proliferation Treaty as possessing nuclear weapons). Many also insisted upon including the three prominent additional states that were sometimes then designated as "nuclear threshold" states, India, Pakistan, and

40. RAMAKER, supra note 7 , at 235.

41. Id. at 253; see also JOHNSON, supra note 15, at 126-37.

42. RAMAKER, supra note 7, at 235-56; JOHNSON, supra note 15, at 109-43; Mackby Still Seeking, supra note 15 , at 272-75.

43. RAMAKER, supra note 7, at 235; JOHNSON, supra note 15 , at 112-15. 
Israel. ${ }^{44}$ (Now, all three, plus North Korea, have clearly crossed that threshold and are acknowledged to possess nuclear weapons. ${ }^{45}$ )

At the same time, participants were also keenly aware of the danger of levying too heavy a burden upon entry into force, because doing so would confer upon each designated state a "veto" over the treaty's effectiveness. ${ }^{46}$ No one wanted to insert that type of "poison pill" into article XIV. Additionally, some countries (notably India) wanted to avoid being labeled by name as pre-requisites for the entry into force, in order to eliminate any implication that they somehow constituted "problem states" for the CTBT. ${ }^{47}$ And some wanted to avoid any direct recognition of the NPT's nuclear weapons possessing states and the threshold states, as if they were being "rewarded" with a special status under the treaty for having previously acquired nuclear arms. ${ }^{48}$

Various states therefore proffered a wide array of competing proposals for the treaty's entry into force, some of which embodied the virtue of relative simplicity, while others contained many moving parts. Most conspicuously, several states dug in their heels on this point, offering little negotiating flexibility over a protracted period, with no consensus emerging. ${ }^{49}$

44. RAMAKER, supra note 7, at 235; 1994-96: Entry into Force Formula, COMPREHENSIVE TEST BAN TREATY ORG. PREP. COMM'N, https://www.ctbto.org/the-treaty/1993-1996-treatynegotiations/1994-96-entry-into-force-formula/ (last visited Jan. 27, 2017); DAHLMAN ET AL., supra note 7, at 77 (noting that at the time when the CTBT negotiators were considering various formulas for entry into force, they became aware that the Chemical Weapons Convention (CWC), a major disarmament agreement abolishing that entire category of weapons, was coming close to fulfilling its relatively simple requirement for entry into force. The CWC specified that effectuation would occur when sixty-five states ratified, without any special qualifications or designations of individual required participants. At that point, it appeared that the CWC might achieve sixty-five ratifications and enter into force without membership by the United States or Russia, by far the leading chemical weapons-possessing states. Although that scenario did not come to pass - both the United States and Russia soon ratified the CWCthe CTBT negotiators were motivated to avoid setting up that sort of possibility); Mackby Still Seeking, supra note 15 , at 273 .

45. See Nuclear Testing supra note 9 (reporting the "box score" of nuclear testing).

46. RAMAKER, supra note 7, at 237-38, 247.

47. RAMAKER, supra note 7, at 237, 252; Ulrika Moller, Explaining Why India Opted Out, in BANNING THE BANG OR THE Bomb? Negotiating the NuCleAR TEST BAN Regime 190, 214-15 (Mordechai Melamud et al. eds., 2014); ThOmas Graham JR., DisArmament SKetches: ThreE DECADES OF ARMS CONTROL AND INTERNATIONAL LAW 253-54 (2002) [hereinafter GRAHAM, Sketches]; JOHNSON, supra note 15, at 118-21.

48. RAMAKER, supra note 7 , at 242.

49. RAMAKER, supra note 7, at 237-39, 248 (observing that "for every suggestion or proposal there was at least one delegation opposed"); JoHnSON, supra note 15, at 117-40; Mackby Still Seeking, supra note 15, at 274; 1994-96: Entry into Force Formula, COMPREHENSIVE TEST BAN TREATy OrG. PreP. COMM'N, https://www.ctbto.org/the-treaty/1993-1996-treaty-negotiations/1994-96-entry-into-forceformula/. 
Ultimately, a core group of states - including China, Russia, the United Kingdom, Pakistan, and Egypt-prevailed with the not-so-Solomonic insistence that article XIV must embrace all the states that might be of some nuclear concern. They pursued different proffered formulas listing from twenty-nine to ninety-three countries, eventually settling on the forty-four designees now included in Annex 2. ${ }^{50}$ The United States resisted this Achilles heel for entry into force, but ultimately conceded the point, hoping that, eventually, the hydraulic pressure of international politics would drive all the necessary states to join the treaty. ${ }^{51}$ If the choice boiled down to a CTBT that might take a long time to effectuate versus the possibility that resisting the hardliners on this issue might result in no CTBT at all, the United States and others backed down. ${ }^{52}$

One intermediate position that attracted substantial interest throughout the negotiations would have accepted the stringent standard for entry into force, but additionally allowed each individual state to "waive" that rigidity for itself, if it so desired, thereby enabling the CTBT to become operational more quickly for the most willing parties. ${ }^{53}$ The leading precedent for that more liberal approach in other arms control treaties, and the possibility of its continuing relevance for the CTBT, are discussed infra. ${ }^{54}$

\section{U.S. Ratification Efforts}

Just as this treaty has been ardently supported by its champions, it has evoked equally entrenched opposition. In the United States, in particular,

50. RAMAKER, supra note 7, at 247-48; Rebecca Johnson, The Role of Civil Society in Negotiating the CTBT, in BANNING the BANG OR THE BOMB? NEGOtiating the NuCleAR TEST BAN Regime 96, 115-16 (Mordechai Melamud et al. eds., 2014) [hereinafter Johnson, Role in Society]; JoHNSON, supra note 15, at 113-41; Mackby, Still Seeking, supra note 15, at 273 (noting that the United States had proposed that CTBT entry into force should be achieved if only 95 percent, rather than all, of the countries on a designated list were to ratify). It is not customary to identify countries directly by name in crafting treaty restrictions of this sort, so the diplomatic artifice is to rely instead upon a list or roster of relevant states that had been originally created for some other purpose and incorporate it by reference.

51. RAMAKER, supra note 7 , at 254 .

52. Id. at 256 (concluding that: "The negotiations could easily have broken down on this issue alone.”); JoHNSON, Role in Society, supra note 50 at 116 (criticizing poor negotiating tactics by participants, which created "an unwieldy, unworkable Article XIV"); GRAHAM, Sketches, supra note 47, at 254-55; JOHNSON, supra note 15, at 122-35; Sabine Bauer and Cormac O'Reilly, The Comprehensive Nuclear-Test-Ban Treaty Organization (CTBTO): Current and Future Role in the Verification Regime of the Nuclear-Test-Ban Treaty, in Nuclear Non-Proliferation in International Law 131, 136 (Jonathan L. Black-Branch and Dieter Fleck eds., vol. II, 2016) (noting that commentators have criticized art. XIV as "the worst entry-into-force provision ever negotiated," but most negotiators did not imagine a delay of more than a few years before entry into force).

53. RAMAKER, supra note 7, at 238, 241-43, 249-52; JOHNSON, supra note 15, at 114-16; Anguel Anastassov, Can the Comprehensive Nuclear-Test-Ban Treaty Be Implemented Before Entry into Force? 55 NETH. INT'L L. REV. 73, 82 (2008).

54. See infra, III.E. 
CTBT has always provoked persistent domestic political turmoil. ${ }^{55}$ Most overtly, partisan resisters in the Senate rejected a resolution of ratification for CTBT by a 51-48 vote on October 13, 1999. ${ }^{56}$ A decade of political gridlock and stagnation followed, with no progress toward U.S ratification. Thereafter, the Obama Administration pledged high priority support for a renewed effort to obtain the two-thirds endorsement necessary to ratify the agreement, but senior spokespersons subsequently acknowledged that the political calculations remained decidedly adverse, and that a long-term strategy of educating and informing the American public and the members of Congress would have to pre-date any renewed legislative consideration. ${ }^{57}$ The political course of CTBT through the next phase of U.S. politics is anybody's guess, but to date, neither the Trump Administration nor the Republican-controlled Senate has signaled any interest in proceeding toward effectuating the treaty. ${ }^{58}$

55. See Edward Ifft, The Comprehensive Nuclear-Test-Ban Treaty and US Security, 23 NONPROLIFERATION REVIEW, nos. 3-4, 385-89 (2016).

56. Chris McIntosh, Framing the CTBT Debate over the U.S. Ratification of the Treaty, in BANNING THE BANG OR THE BOMB? NEgOtIATING THE NuCleAR TEST BAN REgIME 146 (Mordechai Melamud et al. eds., 2014); 1992-2002: The United States and the CTBT, COMPREHENSIVE TEST BAN TREATY ORG. PREP. COMM'N, https:/www.ctbto.org/the-treaty/developments-after-1996/1999-2002the-united-states-and-the-ctbt/ (last visited Jan. 27, 2017); see David S. Jonas, The Comprehensive Nuclear Test Ban Treaty: Current Legal Status in the United States and the Implications of a Nuclear Test Explosion, 39 N.Y.U. J. INT'L L. \& POL. 1007, 1019-26 (Sept. 26, 2007).

57. NiKITIN, supra note 14, at 4-7 (reporting statements by the President, Vice President, and other senior Obama administration officials favoring CTBT but recognizing the necessity of additional preparations before another Senate vote); Hillary Rodham Clinton, U.S. Sec'y of State, Remarks at CTBT Article XIV Conference, New York, NY (Sept. 24, 2009), https://www.ctbto.org/fileadmin/user_upload/Art_14_2009/240909_Morning_Session/240909_US.pdf; Rose Gottemoeller, Acting U.S. Under Sec'y of State, Statement to the Article XIV Conference, United Nations (Sept. 27, 2013), https://www.ctbto.org/fileadmin/user_upload/Art_14_2013/ Statements/united_states.pdf; U.S. Statement to the Comprehensive Nuclear-Test-Ban Treaty Organization's PrepCom 20th Anniversary Ministerial Meeting (June 13, 2016), http://www.state.gov/t/us/2016/258408.htm, archived at https://web.archive.org/web/ 20170120160252/https:/www.state.gov/t/us/2016/258408.htm; Rose Gottemoeller, Rebuilding American Support for the CTBT, 23 NONPROLIFERATION REVIEW, nos. 3-4, 362 (2016).

58. See Masakatsu Ota, Nuclear Test Ban Facing New Challenge on Trump's Watch, KyOdo NEWs, Mar. 9, 2017 (noting that the Republican Party has traditionally been hostile to the CTBT); James Glanz, Rick Perry, as Energy Secretary, May Be Pressed to Resume Nuclear Tests, NEW YORK TIMES, Dec. 27, 2016 (reporting political pressure to return to testing); but see Michael Krepon, Trump and the Bomb: U.S. Nuclear Policy Under the Next Administration, ForeIGN AfF., Nov. 20, 2016, https://www.foreignaffairs.com/articles/2016-11-20/trump-and-bomb, (arguing that: "Trump could surprise everyone by calling on the Senate to proceed with the hearings and then consent for the CTBT's ratification."). 


\section{Verification Debates}

One of the most basic questions confronting any arms control agreement concerns verification of compliance: how can each party be confident that its treaty partners (and potential adversaries) are faithfully complying with their agreed restraints? Especially for a treaty as significant as CTBT, adequate certainty about other states' fidelity is essential, and the bulk of the accord's nearly 100 pages of text is devoted, in one way or another, to that concern. ${ }^{59}$

Three aspects of the CTBT verification apparatus are worth highlighting here. First, the treaty establishes an International Monitoring System (IMS) of unprecedented scope and strength. Under the treaty, a network of 321 monitoring stations and sixteen laboratories is to be constructed or adapted in eighty-nine countries worldwide. These employ four distinct technologies, with state-of-the-art sensors for seismological, radionuclide, hydroacoustic, and infrasound monitoring. The sensors are linked through a dedicated Global Communications Infrastructure, based on a constellation of six satellites, to provide near-real-time reporting of the yield to the International Data Center in Vienna, Austria. The IMS is now more than ninety percent operational, providing voluminous, high-quality, and authenticated data to CTBT participating states, and enabling much greater visibility of any attempted covert nuclear testing. ${ }^{60}$

The second key component of the CTBT verification scheme consists of mechanisms for on-site inspection. In the event of a suspicious event, a challenging party could employ the treaty's detailed and mandatory procedures to trigger a visit by outside observers who would be authorized

59. RAMAKER, supra note 7, at 91-176 (discussing the protracted negotiation over the verification provisions of the CTBT); see Paul Meerts \& Mordechai Melamud, Putting OSI on the Table, in BANNING THE BANG OR THE BOMB? NEgOtiating the NuClEAR TEST BAN REgiMe 326 (Mordechai Melamud et al. eds., 2014); DAHLMAN ET AL., supra note 7, at 25-58.

60. CTBT, supra note 1, art. IV and Protocol, Part 1; Verification Regime, COMPREHENSIVE TEST BAN TREATY ORG. PREP. COMM'N https://www.ctbto.org/verification-regime/ (last visited Jan. 27, 2017) (describing the IMS network, the constellation of satellite communications links, and the International Data Center); Lassina Zerbo, The Challenges to Ratifying the CTBT-Can the No-Test Norm Be Maintained Indefinitely?, EUR. LEADERSHIP NETWORK (Sept. 10, 2013) [hereinafter Zerbo], https://web.archive.org/web/20170314020141/http://www.europeanleadershipnetwork.org/thechallenges-to-ratifying-the-ctbt — can-the-no-test-norm-be-maintained-indefinitely_777.html (estimating the cost of the CTBTO verification network at around \$1 billion); see COMPREHENSIVE TEST Ban Treaty Org. Prep. Comm'n, AnNual Report 2015, 1-27; Stephen Herzog, The Nuclear Test Ban: Technical Opportunities for the New Administration, 47 ARMS CONTROL TODAY, no. 1, 26, (2017) (suggesting improvements in the CTBT monitoring system). 
to probe the suspect location with modern tools and techniques to gather telltale evidence of any clandestine nuclear event. ${ }^{61}$

Finally, the treaty incorporates a series of algorithms for consultation, exchanges of information, and dispute resolution, in the event of any question about treaty compliance. ${ }^{62}$ Those routines would operate through a new dedicated international organization, the Comprehensive Test Ban Treaty Organization (CTBTO), in which all treaty parties would become members. $^{63}$

\section{Provisional Application of the CTBT}

This treaty structure, like several others, provides for provisional operation of some of the key features of the treaty architecture, prior to its formal entry into force. The concept is that essential aspects of the verification apparatus, such as the network of IMS sensors, should be established during the interval between signature and ratification, so they can be fully in service on Day One of the treaty regime. ${ }^{64}$

In this instance, the states that had been early in signing the CTBT also adopted a "Text on the Establishment of a Preparatory Commission" and specified which elements of the treaty structure would become operational immediately. ${ }^{65}$ The Preparatory Commission is to function as a temporary

61. CTBT, supra note 1, art. IV.D and Protocol, Part II; The Final Verification Measure, COMPREHENSIVE TEST BAN TREATY ORG. PREP. COMM'N, https://www.ctbto.org/verificationregime/on-site-inspection/the-final-verification-measure/ (last visited Jan. 27, 2017) (describing preparations for on-site inspection); COMPREHENSIVE TEST BAN TREATY ORG. PREP. COMM'N, ANNUAL REPORT 2015, 33-42.

62. CTBT, supra note 1, arts. V, VI.

63. CTBT, supra note 1, art. II; The Organization, COMPREHENSIVE TEST BAN TREATY ORG. PREP. COMM'N (Jan. 29, 2017), https://www.ctbto.org/the-organization/.

64. CTBT, supra note 1, art. IV.1 (specifying that: "At entry into force of this Treaty, the verification regime shall be capable of meeting the verification requirements of this Treaty."); Establishment, Purpose, and Activities, Comprehensive Test Ban Treaty Org. Prep. Comm'n, https://www.ctbto.org/the-organization/ctbto-preparatory-commission/establishment-purpose-andactivities/ (last visited Jan. 27, 2017) ) (describing the creation and operation of the provisional structures intended to pave the way for full operation of the treaty as soon as it enters into force); see DAHLMAN ET AL., supra note 7, at 99-111; Anastassov, supra note 53, at 89-95; Masahiko Asada, CTBT: Legal Questions Arising from Its Non-Entry-Into-Force, 7 J. CONFLICT \& SECURITY L. 85, 104-13 (2002); see generally RESTATEMENT (THIRD) OF THE FOREIGN RELATIONS L. OF THE UNITED STATES $\S 312 \mathrm{cmt}$. h (AM. LAW INST. 1987) (discussing the concept and operation of provisional application) [hereinafter RESTATEMENT]; Vienna Convention on the Law of Treaties art. 25, May 23, 1969, 1155 U.N.T.S. 331, 8 I.L.M. 679 [hereinafter VCLT] (discussing provisional application of a treaty or part of a treaty); Andrew Michie, The Provisional Application of Arms Control Treaties, 10 J. CONFLICT \& SECURITY L. 345, 356 74 (2005) (discussing examples of provisional application of arms control treaties); ANTHONY AUST, MODERN TREATY LAW AND PRACTICE 172-74 (2d ed. 2007).

65. Comprehensive Nuclear Test Ban Treaty Signatories, Assembly Res. CTBT/MSS/RES/1 (Nov. 27, 1996), https://www.ctbto.org/fileadmin/user_upload/legal/CTBT-MSS-RES-1-e_01.pdf (establishing the Preparatory Commission for the Comprehensive Nuclear Test-Ban Treaty 
surrogate for the eventual CTBTO and to pave the way for that formal successor body. ${ }^{66}$ The signatories indicated that the IMS should be established and networked, and a variety of guidance manuals for the four monitoring technologies prepared. The Preparatory Commission was also assigned an array of tasks regarding the eventual conduct of on-site inspections, such as the development of procedures and formats for designating inspectors and initiating their functions-but the ability to conduct any on-site inspections was not made part of the provisional application. Similarly, the CTBT's consultation and dispute resolution articles are not fully activated until the treaty enters into force. ${ }^{67}$

Provisional implementation of the monitoring apparatus has been highly successful. To date, 288 of the contemplated 337 stations and laboratories have been constructed and certified, and most are steadily providing their input to the International Data Center. A further sixteen stations have been installed but not yet certified, sixteen are under construction, and seventeen are still in the planning stage. ${ }^{68}$ These installations have functioned admirably, such as to detect, locate and identify the North Korean nuclear tests, ensuring a degree of transparency and documentation to those events, and validating the concept of CTBT verification. ${ }^{69}$ In addition, the IMS has generated other major unanticipated

Organization). Unlike for some other treaties, the CTBT negotiators deliberately did not explicitly adopt the term "provisional application" in the CTBT documents. Some observers therefore refer to the current status as "implied" provisional application, or distinguish between provisional application and provisional entry into force. For present purposes, the concepts and structures are operationally similar. See Michie, supra note 64, at 355, 367-73; Anastassov, supra note 53, at 92; Glossary, U.N. TREATY COLLECTION, https://treaties.un.org/pages/overview.aspx?path=overview/glossary/page1 en.xml (providing sections on Provisional Application and Provisional Entry into Force of Treaties); STAFF OF H. COMM. ON

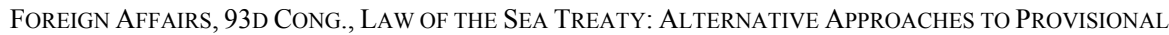
Application (Comm. Print 1974); Robert E. Dalton, Provisional Application of Treaties, in THE OXford Guide TO TREATIES 220-247 (Duncan B. Hollis ed., 2012); Gabriella Venturini, The CTBTO PrepCom at Twenty: Beyond the CTBT?, 23 NONPROLIFERATIOn REV., nos. 3-4, 345, 350 (2016); Bauer and O'Reilly, supra note 52, at 139-43.

66. CTBT Assembly Res. CTBT/MSS/RES/1, 2 (Text on the Establishment of a Preparatory Commission for the Comprehensive Nuclear Test-Ban Treaty Organization).

67. See id. at 8-13 (providing an Indicative List of Verification Tasks of the Preparatory Commission, Appendix to Text on the Establishment of the PrepCom); DAHLMAN ET AL., supra note 7, at 138-42. The CTBTO has undertaken important preparations for the eventual conduct of on-site inspections, such as conducting field exercises and simulations. See NIKITIN, supra note 14, at 27-28; On-Site Inspections, COMPREHENSIVE TeSt BAN TREATY ORG. PREP. COMM'N, https://www.ctbto.org/ specials/integrated-field-exercise-2014/ (last visited Jan. 30, 2017); OLA DAHLMAN ET AL., DETECT AND DETER: CAN COUNTRIES Verify THE NuCleAr TEST BAN? 129-57 (2011).

68. International Monitoring System Status, Comprehensive TeSt BAN TREATy Org. PreP. CoMm'N, https://www.ctbto.org/ (last visited Jan. 30, 2017).

69. 9 September 2016 North Korea Announced Nuclear Test, COMPREHENSIVE TEST BAN TREATY ORG. PREP. COMM'N, https://www.ctbto.org/the-treaty/developments-after-1996/2016-sept-dprkannounced-nuclear-test/ (last visited Jan. 25, 2017); see generally NIKITIN, supra note 14, at 15-21; 
spinoff benefits, such as providing crucial timely warning of seismic events that could generate life-jeopardizing Pacific Rim tsunamis or tracking the plume of radioactive gases from the Fukushima reactor disaster. ${ }^{70}$

The Preparatory Commission and its Provisional Technical Secretariat have become nearly full-fledged international institutions, hosting a wide array of high-level conferences, concluding legally-binding international agreements, building an enduring infrastructure, and operating a budget of $\$ 128,120,000$ in $2016 .^{71}$

At the same time, provisional implementation remains an inadequate substitute for full functionality of the CTBT. For one thing, some countries (China, Egypt, India, Iran, and Pakistan, for example) have been slow to establish the planned IMS facilities on their territories, or unwilling to contribute data from them until the treaty is in force. ${ }^{72}$ Additionally, as noted above, some powerful implementation aspects of the treaty-the ability to demand an on-site inspection, or to make full use of the institutional dispute resolution alternatives - are in abeyance. ${ }^{73}$ And a lingering uncertainty may persist about whether states that have signed the treaty are obliged, by customary international law or by article 18 of the Vienna Convention on the

Simeon Dukic \& Matteo Zerini, The CTBT International Monitoring System: A Tale of Two Tests, TR. \& VERIFY (Verification Research, Training and Info. Ctr., London, U.K.), Autumn 2016, at 9.

70. See Spin-Offs for Disaster Warning and Science, COMPREHENSIVE TEST BAN TREATY ORG. PREP. COMM'N, https:/www.ctbto.org/verification-regime/spin-offs-for-disaster-warning-and-science/ (last visited Jan. 30, 2017); The 11 March Japan Disaster, COMPREHENSIVE TeST BAN Treaty ORG. PREP. COMM'N, https://www.ctbto.org/verification-regime/the-11-march-japan-disaster/ (last visited Jan. 30, 2017).

71. Legal Resources, COMPREHENSIVE TEST BAN TREATY ORg. PREP. COMM'N, https://www.ctbto.org/member-states/legal-resources/ (last visited Jan. 30, 2017) (citing treaties concluded by the CTBTO with countries and international organizations); Establishment, Purpose and Activities, Comprehensive Test BAn Treaty ORg. PreP. COMM'N, https://www.ctbto.org/theorganization/ctbto-preparatory-commission/establishment-purpose-and-activities/ (last visited Jan. 30, 2017) (describing the budget); see generally DAHLMAN ET AL., , supra note 7, at 201-14 (assessing the organization's operations, budgets, and international relations); Asada, supra note 64, at 105-13.

72. Station Profiles, COMPREHENSIVE TEST BAN TREATY ORg. PREP. COMM'N, https://www.ctbto.org/verification-regime/station-profiles/ (last visited Jan. 30, 2017) (showing which stations are not yet operational or certified); NIKITIN, supra note 14, at 13 (noting Iran's 2007 suspension of transmission of data from IMS stations on its territory); Lassina Zerbo, The CTBT at 20: Ambition on the Road to Success, ARMS CONTROL TODAY, Jan./Feb. 2017, at 33 [hereinafter Zerbo, The CTBT at 20] (noting that China has recently begun cooperating more with the CTBTO regarding treaty verification functions).

73. RAMAKER, supra note 7, at 177-200; see Zerbo, The CTBT at 20, supra note 72, at 34 . 
Law of Treaties ${ }^{74}$ (VCLT), to refrain from conducting nuclear tests prior to entry into force. ${ }^{75}$

In addition, some observers have detected worrying signs that the regime of provisional application may not be sustainable indefinitely. The concept of a "temporary" mechanism, after all, was not intended to run forever, yet twenty years have already elapsed since the initial signature of the CTBT. A sense of "fatigue" may undercut some signatories' duty of affiliation with the still-not-perfected institution, and some may begin to question continuing to provide their annual dues, voluntary contributions, or other indicia of commitment to the enterprise. ${ }^{76}$

One view is that a de facto or "virtual" CTBT already exists, and that it is (almost) sufficient for global security needs. The United States, Russia, and China have now refrained from conducting any nuclear tests for more than two decades, and the international political momentum behind the moratoria and provisional application is so strong that perhaps none of them will ever test again, absent some very important adverse developments. ${ }^{77}$ But the stronger view is that there is no substitute for a "real" CTBT, fully in force and with near-universal legal applicability. Until that objective is accomplished, the demand for reliable measures of arms control and non-

74. VCLT, supra note 64, art. 18. Under art. 18 , a state that has signed but not yet ratified a treaty is "obliged to refrain from acts which would defeat the object and purpose" of the treaty. Id. The United States has not ratified the VCLT, but has generally accepted it as binding as an authoritative declaration of customary international law. See Restatement, supra note 64, at Part III, Introductory Note and $\S$ 312(3); Asada, supra note 64, at 98-103.

75. In a September 15, 2016 joint statement, China, France, Russia, the United Kingdom, and the United States recognized that a nuclear explosion "would defeat the object and purpose of the CTBT." Press Release, U.S. Dep't of State, Joint Statement on the Comprehensive Nuclear-Test-Ban Treaty by the Nuclear Nonproliferation Treaty Nuclear-Weapon States (Sept. 15, 2016), http:/www.state.gov/r/pa/prs/ps/2016/09/261993.htm, archived at https:/web.archive.org/web/ 20170119095033/https:/www.state.gov/r/pa/prs/ps/2016/09/261993.htm. The Security Council then endorsed that judgment. S.C. Res. 2310, 4 (Sept. 23, 2016). Regarding the object and purpose of the CTBT, see Jonas, supra note 56, at 1035-40; see Mackay, supra note 7, at 302-05; Asada, supra note 64, at 94-103; Daniel Rietiker, The (Il?)legality of Nuclear Weapons Tests Under International LawFilling the Possible Legal Gap by Ensuring the Comprehensive Test Ban Treaty's Entry into Force, ASIL Insights (The Am. Society of Int'1 Law, Washington, D.C.), Mar. 16, 2017, https://www.asil.org/insights/volume/21/issue/4/illegality-nuclear-weapons-tests-under-internationallaw\%E2\%80\%94filling-possible (arguing that the protracted delay in bringing CTBT into force has undercut the applicability of VCLT art. 18).

76. DAHLMAN ET AL., supra note 7, at 220-21 (noting that CTBT parties have fluctuated in their dues payments, and as of 2007, forty-two states had never paid their assessments); David Axe, Republicans Move to Strip Away Nuclear Test Ban Funding, DAILY BEAST (Feb. 13, 2017), http://www.thedailybeast.com/republicans-move-to-strip-away-nuclear-test-ban-funding (reporting proposed legislation introduced by Sen. Tom Cotton (R-AR) to restrict funding for the CTBTO).

77. See Zerbo, supra note 60 (asserting that "nuclear testing is now widely perceived as a rogue activity."); Bauer and O'Reilly, supra note 52, at 139 (observing that there is a debate about whether a de jure global ban against nuclear testing can already be said to exist). 
proliferation remains unsated. Moreover, the window of opportunity for permanently entrenching the norm against nuclear testing may not remain open indefinitely with the CTBT hanging in limbo. ${ }^{78}$ The picture has now been further complicated by rumblings that some in both the United States and Russia may be contemplating a return to nuclear testing. ${ }^{79}$

\section{Failed Attempts to Square the Circle}

Numerous efforts have been launched to retrieve and sustain the "loose ends" of CTBT provisional application. The treaty's article XIV, while creating the immense obstacle against entry into force, also recognized that impediment, and called for the convening of a conference "to consider and decide by consensus what measures consistent with international law may be undertaken to accelerate the ratification process in order to facilitate the early entry into force of this Treaty." ${ }^{80}$ Nine such "Article XIV conferences" have

78. Conference on Facilitating the Entry into Force of the Comprehensive Nuclear-Test-Ban Treaty, Final Declaration and Measures to Promote the Entry into Force of the Comprehensive NuclearTest-Ban Treaty, I 8. CTBT Art. XIV/2009/6, Annex (Oct. 8, 2009) https://www.ctbto.org/ fileadmin/user_upload/Art_14_2009/CTBT-Art.XIV-2009-6.pdf (participants in the ninth Article XIV Conference conclude that: "Continuing and sustained voluntary adherence to a moratorium is of the highest importance, but does not have the same effect as the entry into force of the Treaty, which offers the global community the prospect of a permanent and legally binding commitment to end nuclear weapon test explosions or any other nuclear explosions."); see Nobuyasu Abe, Cementing the Trend Away from Nuclear Weapons, CTBTO SPECTRUM, Apr. 2015, at 5; Sérgio de Queiroz Duarte, The Nuclear Test-Ban and International Law, CTBTO SPECTRUM, Apr. 2015, at 7; Wolfgang Hoffmann, A View on the Comprehensive Nuclear-Test-Ban Treaty (CTBT), CTBTO SPECTRUM, Apr. 2015, at 8; Kevin Rudd, $A$ U.S.-China Roadmap for CTBT Ratification, CTBTO SpeCtrum, Apr. 2015, at 9; but see Des Browne, Verifying the Nuclear Test-Ban: A Regime That Works, CTBTO SPECTRUM, Apr. 2015, at 6; see Zerbo, supra note 60 (contending that entry into force of the CTBT "is the only guarantee of a legally binding non-testing regime."); Mackby Nonproliferation Verification, supra note 39, at 732 (reporting that some experts opposed provisional application of the CTBT, fearing that "it would provide a screen behind which nonparties could hide and delay the full entry into force indefinitely."); U.N. SCOR, 71st Sess., 7776th mtg. at 8, U.N. Doc. S/PV.7776 (Sept. 23, 2016) (comments of Vitaly Churkin speaking on behalf of the Russian Federation) ("We believe that the moratoriums on nuclear testing, as important as they are, cannot serve as a full-fledged replacement for legally binding international norms. The Treaty, rather than national moratoriums, should be the benchmark for States' responsible behaviour."); Secretary-General's Message on the International Day against Nuclear Tests, United Nations, August 29, 2017, https://www.un.org/sg/en/content/sg/statement/2017-08-29/secretary-generals-message-internationalday-against-nuclear-tests (asserting that "it is essential" that the CTBT enter into force).

79. See William J. Broad \& David E. Sanger, Race for Latest Class of Nuclear Arms Threatens to Revive Cold War, N.Y. TIMES (Apr. 16, 2016), https://www.nytimes.com/2016/04/17/science/atombomb-nuclear-weapons-hgv-arms-race-russia-china.html?mcubz=3 (citing former Secretary of Defense William J. Perry as worrying that Russia might resume testing); NIKITIN, supra note 14, at 9 (quoting a Russian scholar asserting that Russia might not long sustain a situation in which it has ratified the CTBT while the United States and China have not); see Glanz, supra note 58 (noting Trump administration may consider resuming testing); John M. Donnelly, Pentagon Panel Urges Trump Team to Expand Nuclear Options, RoLl CALL (Feb. 2, 2017), https://www.rollcall.com/news/policy/

pentagon-panel-urges-trump-team-expand-nuclear-options; Ota, supra note 58; Rietiker, supra note 75.

80. CTBT, supra note 1, art. XIV.2; see RAMAKER, supra note 7, at 249. 
been convened, the most recent in September 2015 at the United Nations headquarters in New York. These conclaves have succeeded in rallying global support for the treaty, in launching outreach activities toward the nonparty states, in underscoring the importance of garnering additional ratifications, and in building provisional application, but they have not yet managed to bring the key outliers much closer to ratification. ${ }^{81}$ In particular, these conferences have no power to alter the treaty's constraints upon entry into force, or to adopt any other legally binding measures to ameliorate the article XIV problem. ${ }^{82}$

Numerous other senior-level events, ${ }^{83}$ as well as annual resolutions in the U.N. General Assembly ${ }^{84}$ and occasional pronouncements of the U.N. Security Council ${ }^{85}$ have similarly attempted to advance the CTBT, but have not yet accomplished the ultimate objective. Brainstorming about other potential "measures consistent with international law" has generated creative

81. Conference on Facilitating the Entry into Force of the Comprehensive Nuclear-Test-Ban Treaty, Final Declaration and Measures to Promote the Entry into Force of the Comprehensive NuclearTest-Ban Treaty (Sep. 29, 2015), https://www.ctbto.org/fileadmin/user_upload/Art_14_2015/ FINAL_DECLARATION.pdf; Conference on Facilitating the Entry into Force of the Comprehensive Nuclear-Test-Ban Treaty, Activities Undertaken by Signatory and Ratifying States under Measure (J) of the Final Declaration of the 2013 Conference on Facilitating the Entry into Force of the Treaty in the Period June 2013-May 2015, CTBT-Art.XIV/2015/4 (Sep. 18, 2015), https://www.ctbto.org/ fileadmin/user upload/Art 14 2015/CTBT Art XIV 2015 4.pdf; Conference on Facilitating the Entry into Force of the Comprehensive Nuclear-Test-Ban Treaty, Background Document by the Provisional Technical Secretariat of the Preparatory Commission for the Comprehensive Nuclear-Test-Ban Treaty Organization, Prepared for the Conference on Facilitating the Entry into Force of the CTBT (New York, 2015), CTBT-Art.XIV/2015/3 (July 30, 2015) https://www.ctbto.org/fileadmin/user_upload/ Art_14_2015/CTBT_Art_XIV_2015_3_E.pdf.

82. See JoHNSON, supra note 15, at 131-37.

83. 2016: Eighth Ministerial Meeting of the Friends of the CTBT, COMPREHENSIVE TEST BAN TREATY ORG. PREP. COMM'N, https://www.ctbto.org/the-treaty/ctbt-ministerial-meetings/2016/ (last visited Jan. 30, 2017) (reporting about the September 2016 meeting of foreign ministers, the latest in a series of conferences of senior officials intended to build support for CTBT entry into force); Building $a$ Nuclear-Weapon-Free World, PARLIAMENTARIANS FOR NUCLEAR NON-PROLIFERATION AND DISARMAMENT, http://www.pnnd.org/event/building-political-momentum-nuclear-disarmament (last visited Jan. 30, 2017) (describing a recent international conference to support CTBT); see NIKITIN, supra note 14, at 31-36 (discussing international efforts on behalf of CTBT); COMPREHENSIVE TEST BAN Treaty Org. Prep. COMM'N, ANNUAl Report 2015, at 51-58 (2015) (describing CTBTO outreach efforts)

84. See generally G.A. Res. 71/86 (Dec. 5, 2016); G.A. Res. 70/73 (Dec. 7, 2015); G.A. Res. 69/81 (Dec. 2, 2014); G.A. Res. 68/68 (Dec. 5, 2013) (stressing support for CTBT and reiterating the encouragement of states to join the treaty).

85. See generally S.C. Res. 2310 (Sept. 23, 2016) (urging states, especially the remaining Annex 2 holdouts, to join the CTBT without delay); S.C. Res. 1887 (Sept. 24, 2009) (calling on states to sign and ratify the CTBT); Joint Statement on the Comprehensive Nuclear-Test-Ban Treaty by the Nuclear Nonproliferation Treaty Nuclear-Weapon States, September 15, 2016, https://20092017.state.gov/r/pa/prs/ps/2016/09/261993.htm (reaffirming their commitment to bring the CTBT into force) 
thinking about additional alternative mechanisms for working around the constraints of article XIV, but to date none of them has been implemented. ${ }^{86}$

The sad fact, then, is that despite the earnest desire of the vast majority of the world's countries and people, and despite the profound benefits that a CTBT would provide for global and national security, the treaty is unlikely to be perfected - entry into force remains chimerical, even twenty years after signature of the treaty. The regime of provisional application, for all its accomplishment, remains an inadequate substitute.

\section{THE WORK-AROUND: AN IMPLEMENTING AGREEMENT}

What should be done at this point to rescue the CTBT after so many other efforts have failed? This part of the Article discusses what the treaty negotiators really should have written into article XIV; what international law allows regarding altering the text of a treaty at different stages of its development; what a proposed Implementing Agreement could consist of; and what precedents exist for this work-around.

\section{A. Manageable Entry into Force Provisions}

Several treaties, in the field of arms control and elsewhere, share the CTBT's problem of needing to ensure that the obligations are widely and simultaneously shared by many states - in many circumstances, the early adopters might be disadvantaged if they are not promptly joined by numerous others. But there are ways to serve that purpose without so disabling the ultimate entry into force. ${ }^{87}$

86. RAMAKER, supra note 7, at 12 (discussing a 1991 conference that was convened to consider amending the LTBT to convert it into a CTBT); see, e.g., JOHNSON, supra note 15, at 38-39; see Franz Cede, Enhance the Legal Status of the CTBTO Pending the Treaty Entry into Force, in BANNING THE BANG OR the Bomb? Negotiating the Nuclear Test Ban Regime 227 (Mordechai Melamud et al. eds., 2014) (recommending improvements in the CTBT's provisional implementing organization); Thomas Graham, Jr., A New Pathway to Prohibiting Nuclear Testing, WMD JunCTION (June 3, 2014), http://wmdjunction.com/140603_prohibiting_nuclear_testing.htm archived at https://web.archive.org/ web/20161118050231/http://wmdjunction.com/140603_prohibiting_nuclear_testing.htm (proposing that the U.N. Security Council could effectuate a test ban via a binding resolution pursuant to chapter VII of the U.N. Charter); see generally David A. Koplow, Nuclear Arms Control by a Pen and a Phone: Effectuating the Comprehensive Test Ban Treaty Without Ratification, 46 GEO. J. OF INT'L L. 475 (2015). Some have detected a substantial diminution in states' interest in using the formal mechanisms of legallybinding treaties for effectuating international arrangements, with new a preference for "soft law" alternatives that can be quicker, easier and more flexible. See generally Joost Pauwelyn, Ramses A. Wessel \& Jan Wouters, When Structures Become Shackles: Stagnation and Dynamics in International Lawmaking, 25 EUR. J. OF INT'L. L. 733 (2014); Timothy Meyer, Collective Decision-making in International Governance, AJIL UNBOUND (Apr. 28, 2014), https://www.asil.org/blogs/collectivedecision-making-international-governance-agora-end-treaties. Perhaps this soft law approach could lead to new restrictions on nuclear testing, but it has not yet done so.

87. See AUST, supra note 64, at 163-68 (providing a roster of possible entry into force provisions). 
One common alternative is to specify that the treaty will enter into force only when it has been ratified by a sizeable number of states-forty or sixtyfive, for example (although some treaties are content with as few as twenty). ${ }^{88}$ An important variant is to specify that the immediate membership by some specific states is required. Both the LTBT and the NPT, for example, were conditioned upon ratification by the United States, the Soviet Union, and the United Kingdom. ${ }^{89}$ Notably, the circumstances of international politics at the time those two instruments were concluded did not make the prompt participation of either France or China likely, and negotiators were not inclined to wait for them. Both France and China joined the NPT more than twenty years later, but neither has ever signed or acceded to the LTBT. $^{90}$

Another creative alternative is to set a very high criterion for entry into force, but then to allow each individual state the option of waiving that

88. See, e.g., Convention on Prohibitions or Restrictions on the Use of Certain Conventional Weapons Which May Be Deemed To Be Excessively Injurious or To Have Indiscriminate Effects art. 5.1, Oct. 10, 1980, 1342 U.N.T.S. 137, [hereinafter CCW] (entered into force December 2, 1983, entered into force for the United States September 24, 1995) (requiring ratification by twenty states in order to achieve entry into force); Convention on the Prohibition of the Use, Stockpiling, Production and Transfer of Anti-Personnel Mines and on their Destruction art. 17.1, Sept. 18, 1997, 2056 U.N.T.S. 211 [hereinafter Ottawa Convention] (requiring forty states' instruments of ratification); Arms Trade Treaty art. 22.1, June 3, 2013, U.N. TREATY COLLECTION, https://reaties.un.org/ doc/Publication/UNTS/No\%20Volume/52373/Part/I-52373-08000002803628c4.pdf (requiring fifty states); LoSC, supra note 4, art. 308.1 (requiring sixty instruments); Convention on the Prohibition of the Development, Production, Stockpiling and Use of Chemical Weapons and on Their Destruction art. XXI, Jan. 13, 1993, 1974 U.N.T.S. 45 (entered into force April 29, 1997) (requiring ratification by sixty-five states); Lisa Tabassi, The Nuclear Test Ban: Lex Lata or de Lege Ferenda?, 14 J. CONFLICT \& SECURITY L. 309, 317 (2009) (presenting a chart summarizing the entry into force requirements for several arms control treaties); Michie, supra note 64, at 348-49. See also Treaty on Conventional Armed Forces in Europe art. XXII.2, Nov. 19, 1990, 30 I.L.M. 1 [hereinafter Conventional Forces in Europe Treaty or CFE Treaty] (entered into force July 17, 1992) (requiring ratification by all twenty-two states listed in the treaty's preamble) for which the unanimity requirement has proven problematic in adapting the treaty to new security circumstances in Europe. See GRAHAM \& LAVERA, supra note 12, at 596-97.

89. See LTBT, supra note 16, art. III.3 (treaty enters into force when ratified by the three states designated as "Original Parties," the Soviet Union, the United Kingdom, and the United States). Some treaties combine approaches, requiring ratification by a selected number of states, and additionally specifying that certain states must be included in that number. See, e.g., NPT, supra note 2, art. IX.3 (requiring ratification by forty states in addition to the three depositaries, the Soviet Union, the United Kingdom, and the United States); Convention on the Prohibition of the Development, Production and Stockpiling of Bacteriological (Biological) and Toxin Weapons and on Their Destruction, art. XIV.3, Apr. 10, 1972, 26 U.S.T. 583, (requiring twenty-two states plus the usual three depositaries); Treaty on Open Skies, art. XVII.2, Mar. 24, 1992, S. TREATY DoC. No. 102-37 (1992) (requiring twenty states, specifically including Canada and Hungary as depositaries); Michie, supra note 64, at 349-51.

90. See Treaty on the Non-Proliferation of Nuclear Weapons, Status of the Treaty, UNODA, http://disarmament.un.org/treaties/t/npt (last visited Jan. 30, 2017) (China joined the NPT on March 9, 1992 and France joined on August 3, 1992);Treaty Banning Nuclear Weapon Tests in the Atmosphere, in Outer Space and Under Water, U.S. DEP'T OF STATE, http://www.state.gov/t/isn/4797.htm (neither France nor China has joined the LTBT); JOHNSON, supra note 15, at 111-12. 
stringency, so the treaty can become operational for it (and for other likeminded ratifiers) even if dogged holdouts remain. The best illustration of this approach comes from the 1967 Treaty of Tlatelolco, creating a nuclear weapons free zone for Latin America. ${ }^{91}$ There, article 28 nominally conditions entry into force upon ratification of the treaty by all the states of Latin America, as well as upon ratification of two additional protocols by all the states outside the region who were eligible to join them. ${ }^{92}$ To soften that universality requirement, however, the treaty also grants each signatory the "imprescriptible right to waive, wholly or in part" the limitation, via a declaration formulated at the time it deposits its instrument of ratification or subsequently. ${ }^{93}$

Taking advantage of that structure, many states did waive the limitsand treaty advocates automatically urged all eligible states to do so-so the treaty gradually entered into force for many Latin American countries seriatim, long before it achieved "full" operational status. ${ }^{94}$ Within eight years of its signing, the treaty had entered into force for about three-quarters of the then-eligible states. Prominent holdouts included regional powers Argentina (which had signed the treaty in 1967, but not ratified); Brazil and Chile (both of which had signed and ratified, but declined to exercise the article 28 waiver); and Cuba (which had not signed). ${ }^{95}$ Years later, in a dramatic, coordinated volte-face, the first three of those countries joined the treaty (and waived the restriction on entry into force) in 1994. Cuba joined

91. Treaty for the Prohibition of Nuclear Weapons in Latin America and the Caribbean, Feb. 14, 1967, 634 U.N.T.S. 326 [hereinafter Treaty of Tlatelolco] (entered into force Apr. 22, 1968); see generally, GRAHAM \& LAVERA, supra note 12, at 42-45; John R. Redick, Nuclear-Weapon-Free Zones, in 2 ENCYClOPEDIA OF ARMS CONTROL AND DisARMAMENT 1079, 1081-83 (Richard Dean Burns ed., 1993); see generally John R. Redick, The Tlatelolco Regime and Nonproliferation in Latin America, 35 INT'L ORG. 103 (1981).

92. Treaty of Tlatelolco, supra note 91, art. 28. Protocol I calls upon nations located outside Latin America to apply the treaty's provisions to their territories (colonies or other dependencies) located inside the zone. Protocol II requires the countries possessing nuclear weapons to respect the non-nuclear nature of the zone and to refrain from threatening or using nuclear weapons against treaty parties. $I d$. Additional Protocol I, II.

93. Id. art. 28.2. See Davis R. Robinson, The Treaty of Tlatelolco and the United States: A Latin American Nuclear Free Zone, 64 AM. J. INT'L L. 282, 292 (1970) (describing the waiver provision as the result of a compromise between negotiators from Brazil and Mexico regarding the stringency of the entry into force requirement).

94. Int'L LaW \& Policy Inst. (ILPI), Spelling Tlatelolco: An Overview of the History AND Politics of NuClear Non-Proliferation DisARMAMENT in LATIN AMERICA AND THE CARIBBEAN 10-11 (2016), http://nwp.ilpi.org/wp-content/uploads/2016/07/BP02-16_GRULAC-REV12.pdf; Redick (1993); Treaty of Tlatelolco, supra note 91, art. 28.

95. ILPI, supra note 94, at 10; Treaty for the Prohibition of Nuclear Weapons in Latin America and the Caribbean, Status of the Treaty, opened for signature Fed. 14, 1967, 634 U.N.T.S. 326 [hereinafter Status of Treaty]. 
in only in 2002, so the treaty then entered into force fully for its thirty-three parties. $^{96}$

Another variant would be for the treaty to initially specify relatively "tough" criteria for entry into force, but then to permit modification of that rigidity, if necessary, by a subsequent conference of the states that had signed or ratified. That later assemblage could be empowered to bring the treaty into force for some or all of the assenting states, even if the original high quota were not yet met. ${ }^{97}$

Most treaty regimes, therefore, contemplate a broad array of international politics regarding entry into force. A state can use its potential ratification as a bargaining chip to induce another state to behave likewise; together, they can try to incentivize others to follow suit. A state can focus its attention upon one or more other states of particular concern, pledging to join the treaty as soon as it or they do-and that degree of "linkage" can generate considerable leverage. Sometimes, of course, that kind of interwoven politics is frustrated, and the targeted state continues nonetheless to resist pressure to join the treaty, but the ability to allow even tacit quid pro quo negotiations over ratification can prove salutary for building a bandwagon effect toward entry into force. ${ }^{98}$

In fact, most arms control treaties have grown only slowly and incrementally toward universal membership. The NPT, for example, was opened for signature in 1968, and thirty-eight states had ratified it by 1970 , but many more parties drifted in later. Notably, several countries that are now designated as essential Annex 2 members for the CTBT chose to affiliate with the NPT only after it had been in force for some years, including Belgium, Germany, and the Netherlands (1975), Japan (1976) Switzerland (1977), Indonesia (1979), North Korea (1985), Spain (1987), China and France (1992), Argentina (1995) and Brazil (1998). Moreover, four key players, India, Israel, North Korea and Pakistan, have abstained

96. ILPI, supra note 94, at 15-16; Status of Treaty, supra note 95; Sergio González Gálvez, Thirty Years of Experience Towards the Consolidation of the First Nuclear-Weapon-Free Zone in the World, in NuClear-WeApon-Free Zones IN THE $21^{\text {ST }}$ CENTURY 3, 4 (Pericles Gasparini Alves \& Daiana Belinda Cipollone eds., 1997).

97. Something akin to this structure was written into the provisions of the NPT, supra note 2, regarding duration, rather than entry into force. For that treaty, the initial period of effectiveness was limited to twenty-five years. At that point, a conference was convened "to decide whether the Treaty shall continue in force indefinitely, or shall be extended for an additional fixed period or periods." Id. art. X. At the 1995 conference, the parties decided by consensus to extend the treaty indefinitely. GRAHAM \& LAVERA, supra note 12, at 106. In contrast, the CTBT Article XIV conferences, discussed supra text accompanying notes $80-82$, do not have the authority to make legally binding decisions.

98. See Gálvez, supra note 96, at 4 (citing an allegedly inevitable "expansive force" for all treaties, enabling them to grow beyond their initial nucleus of original parties). 
from the NPT, as they have from the CTBT. The NPT currently boasts 191 parties, and is the most nearly universal of arms control treaties. ${ }^{99}$

The LTBT likewise drew many adherents promptly after its 1963 opening for signature, but latecomers among the states that are now identified in the CTBT's Annex 2 included Bangladesh and Colombia (1985), Argentina (1986), and Pakistan (1988), while China, France, North Korea, Vietnam, and Zaire have still not joined. Under the more restrictive approach of the CTBT, those holdouts would still be blocking entry into force for the LTBT, despite the wishes of its 125 current parties. ${ }^{100}$

\section{B. Altering a Treaty Text}

A treaty text often remains something of a work-in-progress for an extended period of time, and international law allows modification of the draft instrument to suit the participants' evolving needs and perceptions. For present purposes, it is convenient to discern three different stages at which a document might be altered: early (i.e., before signature, or at least before ratification); late (after the treaty has entered into force); and middle (between signature or ratification and entry into force). The first two are relatively easy, at least legally, even if profound political problems may persist; the third case, central to the CTBT case study, is far more problematic and rare.

In the first instance, while negotiations are still underway, the evolving text of an emerging treaty is quite fluid. The document molded by ambassadors and their delegations is typically styled as being "ad referendum, " meaning that approval from national capital authorities is still pending. Because "nothing is agreed until everything is agreed," a text may be subject to re-opening, even late in the negotiations; it may be disruptive, but is not legally problematic, to propose re-working segments of text that had been addressed (and tentatively resolved) much earlier. ${ }^{101}$ The gyrations at the end of the Cold War, for example, roiled the process of concluding the 1990 Conventional Forces in Europe Treaty, ${ }^{102}$ requiring quick last-minute modification of even key elements such as the formal names of some of the

99. Treaty on the Non-Proliferation of Nuclear Weapons, Status of the Treaty, U.N. OfFICE FOR DISARMAMENT AFFAIRS (UNODA), http://disarmament.un.org/treaties/t/npt (last visited Nov. 29, 2017). India, Israel, and Pakistan have never joined the NPT; North Korea had joined, but then withdrew. Id.

100. Treaty Banning Nuclear Weapon Tests in the Atmosphere, in Outer Space and Under Water, Status of the Treaty, U.N. OFFICE FOR DISARMAMENT AFFAIRS (UNODA), http://disarmament.un.org/treaties/t/test_ban (last visited Nov. 29, 2017).

101. See, e.g., Shabtai Rosenne, The United Nations Convention on the Law of the Sea, 1982 The Application of Part XI: An Element of Background, 29 ISR. L. REV. 491, app. (1995) (discussing various alternatives for changing the original contents of the LoSC).

102. CFE Treaty, supra note 88 . 
newly emerging formerly Soviet participating countries. ${ }^{103}$ In aberrational cases, the text of the treaty may have to be altered at or even after signature. ${ }^{104}$

Second, at the other end of the process, once the treaty has entered into force, the mechanism for altering it is usually legally unproblematic, too-a well-drafted treaty will contain clear provisions governing these types of changes. ${ }^{105}$ Traditionally, a formal amendment to a treaty is almost the same as a whole new treaty, requiring the parties to jump through all the legal and procedural hoops they dealt with in creating the treaty in the first place (usually requiring both signature and ratification, with all the accompanying international and domestic political burdens). Some treaties are crafted to be especially difficult to amend, while others are procedurally more amenable. ${ }^{106}$ Sometimes the amendment process carries its own entry-intoforce thresholds, requiring some substantial degree of consensus among the parties before the modification can become viable for any of them. ${ }^{107}$ The amendment might be big or small, might alter the existing text in major or minor degree, and might be controversial among the parties or not. Overall, treaty amendments are a fairly common, routine phenomenon. ${ }^{108}$ In some

103. GRAHAM, Sketches, supra note 47, at 207-09 (describing last-minute modifications in the CFE Treaty structure, required by the sudden breakup of the U.S.S.R. and the emergence of additional states who would have to be subject to the treaty).

104. See, e.g., Treaty Compliance, OfFICE OF THE UNDER SEC'Y OF DEF. FOR ACQUISITION, TeCH., AND LOGISTICS, http://www.acq.osd.mil/TC/treaties/start1/other/corresp/corrigenda.htm (last visited Jan. 30,2017 ) (finding diplomatic correspondence to correct errors discovered in the START I nuclear arms control treaty months after it had been signed by the United States and the Soviet Union); Treaty on the Reduction and Limitation of Strategic Offensive Arms, U.S.-USSR, July 31, 1991, S. TREATY Doc. No. 102-20 (1991); VCLT, supra note 64, art. 79 (discussing procedures for correcting errors in the text of a signed treaty).

105. See, e.g., LTBT, supra note 16, art. II; NPT, supra note 2, art. VIII; CTBT, supra note 1, art. VII.

106. The CTBT is particularly difficult to amend; the process requires a positive vote by a majority of treaty parties at an Amendment Conference, with no party casting a negative vote, so even a single objecting party can veto any amendment. CTBT, supra note 1, art. VII.5. Likewise, the LoSC amendment process is so cumbersome that it has never been successfully invoked. Irina Buga, Between Stability and Change in the Law of the Sea Convention: Subsequent Practice, Treaty Modification, and Regime Interaction, in OXFORD HANDBOOK OF THE LAW OF THE SEA 2 (Donald R. Rothwell et. al. eds., 2015).

107. Under the NPT, for example, an amendment requires the approval by a majority of all parties, including the approval by all five parties recognized as possessing nuclear weapons, and by all other parties who are members of the Board of Governors of the International Atomic Energy Agency. NPT, supra note 2, art. VIII.2.

108. 2016 Treaties and Agreements, U.S. DEP'T OF STATE, http://www.state.gov/s/1/treaty/tias/2016/ (last visited Jan. 30, 2017) (listing numerous new and amended or extended agreements); see generally Malgosia Fitzmaurice \& Panos Merkouris, Re-Shaping Treaties While Balancing Interests of Stability and Change: Critical Issues in the Amendment/Modification/Revision of Treaties, 21 AUSTRIA REV. INT'L \& EUR. L. (forthcoming 2018) (studying the frequency and variability of treaty amendment provisions); see generally AUST, supra note 64, at 262-76. 
instances, the treaty incorporates an additional layer of complexity, by establishing two distinct pathways for modifications. There can be both a formal amendment mechanism, as described above, for large or substantial changes, and a more expedited alternative, applicable to smaller modifications of a technical, administrative, or procedural nature, which can be effectuated without a ratification process. ${ }^{109}$

The third, middle position, however, where the CTBT currently stands, is more legally complex and novel. International practice rarely confronts the dilemma of a treaty that has been negotiated, signed by scores of countries and ratified by many or most of them, and still not entered into force before the need for alteration becomes prominent. There is more to it than just re-opening the negotiations (because doing so would effectively throw away the accumulated ratifications and the years of practice under the provisional application) and there is less to it than a formal amendment (because until the treaty is in force, no portions of it, including the amendment power ${ }^{110}$ are functional). Pointedly, in the case of CTBT, the treaty likely cannot become operational until the entry into force provisions are altered; but conversely, the amendment provisions cannot be used to ease the entry into force procedure until after the treaty is effectuated. ${ }^{111}$

The VCLT provisions regarding amendment and modification of treaties are of only marginal assistance here. Articles 40 and 41 establish that ordinarily, every party to a multilateral treaty is entitled to participate in the development of an amendment, and that the amendment is not binding upon any state that does not accept it. Two or more parties to a multilateral treaty may ordinarily agree to amend its operation among themselves, but this subsequent text has no effect upon their obligations vis-à-vis parties that cling to only the original agreement. ${ }^{112}$

VCLT article 30 adds that in the event of successive treaties relating to the same subject matter, the newer instrument will generally prevail among parties to both documents. But as between a state that has joined both

109. See, e.g., CTBT, supra note 1, art. VII.7-8; LoSC, supra note 4, art. 313; AUST, supra note 64, at 268. A treaty can also be modified by the subsequent practice of the parties and by newly-evolving customary international law. Buga, supra note 106, at 1 .

110. RAMAKER, supra note 7, at 201-07 (discussing the negotiation of the CTBT amendment provisions).

111. Note that pursuant to VCLT art. 24.4, a treaty's formal provisions regarding its own signature, ratification, reservations, and the like will necessarily apply from the time of adoption of the text, but this mechanism does not apply to the amendment powers. VCLT, supra note 64, art. 24.4.

112. VCLT, supra note 64 , arts. 40,41 . A state that joins the treaty after the amendment has entered into force would ordinarily be considered a party to the agreement as amended. Id. art. 40.5. 
documents and a state that has joined only one, the treaty that they have both accepted will provide the governing rules. ${ }^{113}$

As elaborated in the immediately following section, this Article proposes, in effect, a successive treaty-an Implementing Agreement dealing with the same subject matter as the CTBT, to be concluded by as many states as possible, and to modify inter se the CTBT's original provisions regarding entry into force. ${ }^{114}$

\section{The Proposed Implementing Agreement}

This section describes the proposed pathway for modifying the entry into force provisions of the CTBT; it paves the way for the comparison to the Law of the Sea Convention precedent (discussed in section D) and for the presentation of the draft text of my proffered document (displayed in Part IV of the Article). This section highlights two aspects of the Implementing Agreement, concerning substance and procedure.

Substantively, the content of the Implementing Agreement is to incorporate by reference the entire contents of the CTBT, and in addition to introduce into the CTBT's article XIV a waiver provision, based on the Treaty of Tlatelolco model. ${ }^{115}$ That new power would enable each participating state to speak for itself regarding the timing of entry into force of the test ban, rather than being held hostage to the whims of the most recalcitrant among the forty-four Annex 2 states. The waiver is optional, of course, and each state could decide to stand pat with the original provision, so the test ban would not become functional for that state until all forty-four had ratified. But the hope and expectation would be that many countries, if

113. VCLT, supra note 64 , art. 30 . VCLT art. 31.3 provides that in interpreting a treaty, "[a]ny subsequent agreement between the parties regarding the interpretation of the treaty or the application of its provisions" shall also be taken into account. Under VCLT art. 59, a treaty may be terminated by the conclusion of a subsequent treaty dealing with the same subject matter, if that is the intention of the parties, or if the new treaty is incompatible with the original. AUST, supra note 64, at 215-29. Masahiko Asada, The NPT and the IAEA Additional Protocol, in Nuclear Non-Proliferation in International Law 95, 107-10 (Jonathan L. Black-Branch and Dieter Fleck eds., vol. II, 2016). Here, the intention would be to alter the original CTBT provisions, not to create a novation that would replace the entire treaty.

114. Another illustration of this type of practice in the realm of arms control concerns the international legal restraints on anti-personnel land mines. There, two independent, somewhat competing, treaties co-exist: Amended Protocol II of the Convention on Certain Conventional Weapons (which limits, but does not prohibit mines) and the Ottawa Convention (which bans mines outright). See CCW, supra note 88, at Protocol II, art. 1; Ottawa Convention, supra note 88, art.1. Some states (such as the United States, Russia, and China) have joined only the CCW protocol; some (such as most members of NATO) have joined the Ottawa Convention; some have joined both (but it is the more restrictive Ottawa Convention that would be controlling); and some have joined neither. The approach in this Article is to merge the two test ban instruments, not to retain them as competing alternatives.

115. See Treaty of Tlatelolco, supra note 91, art. 28. 
freed from the binds of article XIV, would opt to make legally binding the mechanisms that they have been observing provisionally for many years.

In my proposed version of an Implementing Agreement, each state would enjoy multiple options: to have the test ban become effective for itself immediately; to insert a one year delay (to see whether other states-either in general, or states of particular concern-were joining); and to revert to the original article XIV process. Moreover, a state would be permitted to change its mind, becoming more (or less) accommodating, by switching from its original position and either accepting or delaying the CTBT's effectiveness for itself. $^{116}$

As a procedural matter, the proposed Implementing Agreement would allow an expedited or simplified algorithm governing its own entry into force. Unlike the CTBT and most other major arms control treaties, the Implementing Agreement would not automatically require signaturefollowed-by-ratification. ${ }^{117}$ Instead, each state could decide for itself whether to join the Implementing Agreement via: (a) definitive signature, effective immediately; ${ }^{118}$ (b) signature followed by a one-year delay (again, to assess whether other states were following suit), but not requiring the further step of ratification; or (c) traditional signature and ratification. As before, each state would enjoy the power to make its own unilateral decision about this process, but the purpose of the exercise is to allow and to encourage states to join the Implementing Agreement swiftly, including avoiding the ratification process, where that domestic constitutional step might incur substantial delay. As before, a state would be allowed to change its mind, bringing the Implementing Agreement into force sooner (or later) than it had originally scheduled.

Some states, of course, would be unlikely to change either the substance or the procedure of their original CTBT posture - they would prefer to retain the "default setting" of the current article XIV. At the other extreme, some activist states might leap at the opportunity to exercise leadership in

116. Yet another alternative could be to allow states who sign the Implementing Agreement to apply it provisionally, and through that mechanism, to apply the entire CTBT provisionally, pending entry into force of the Implementing Agreement. That approach would operationalize the entire CTBT, rather than only the provisions that are currently being honored. The Law of the Sea Convention Implementing Agreement, discussed infra, provides a contingency for this type of provisional application. LoSC Implementing Agreement, infra note 134, art. 7. For the CTBT, however, what is desired at this point is a mechanism for true entry into force, not an enhancement of its current provisional application.

117. See VCLT, supra note 64 , arts. 11-16, 24 (specifying that a treaty may provide that a state may express its consent to be bound through signature alone).

118. See id. art. 12 (providing that a state's consent to be bound to a treaty may be expressed by signature alone). 
effectuating the test ban, by bringing the Implementing Agreement into force for themselves immediately, and also exercising the immediate waiver.

Still other states might exploit the opportunity for additional international gamesmanship, bargaining that "I will act, if you do," and they could play that game at both the stage of entry into force of the Implementing Agreement and at exercise of the waiver. The United States, for example, might determine that the test ban should not become operational for itself until it was likewise binding upon Russia and China (at least) but that it was not necessary for those three nuclear behemoths to await the endorsement by North Korea. Alternatively, a more aggressive approach could be to announce a policy of waiting to effectuate the CTBT until, say, India and Pakistan had likewise affiliated with the treaty-but if that device ultimately proved unavailing for some years, the United States, Russia and China could change tactics and proceed to consummate the treaty anyway (along with, presumably, dozens of other like-minded states eager to see the CTBT become entrenched).

Importantly, this Implementing Agreement is not an amendment to the CTBT - that route is not available until the CTBT is in force. But it is a legally binding tool, and it allows the participating states to bring the entire CTBT into force for themselves, not just the parts designated in 1996 as being worthy of provisional application. To emphasize, under this Implementing Agreement and waiver approach, the participating states would be instituting by reference the complete CTBT as originally crafted, except for article XIV; they would not be allowed to pick and choose other individual elements of the treaty to incorporate or disregard. ${ }^{119}$

As a technical matter, it is not truly the 1996 CTBT that is being brought into force by this mechanism. Analytically, it is the Implementing Agreement that becomes legally operational; that instrument incorporates the exact contents of the original CTBT (except for article XIV), but they are separate legal tools. ${ }^{120}$ Some of the consequences of this distinction are discussed infra, but as a shorthand expression, it is convenient to assert that the process proposed here does-indirectly-legally effectuate the full substance of the antecedent CTBT.

For domestic U.S. purposes, if the Implementing Agreement were to become available before the United States ratified the CTBT, then

119. This restrictive approach is consistent with that of the CTBT, which does not allow reservations to the articles and annexes of the treaty, only to the protocol and its annexes. CTBT, supra note 1, art. $\mathrm{XV}$.

120. Under its terms, the 1996 CTBT itself cannot enter into force other than via its article XIV. Id. art. XIV. The work-around proposed in this Article, in effect, incorporates by reference the contents of the earlier treaty, but what comes into force is the "copy" of the CTBT, rather than the "original." 
presumably the two documents would be packaged together, presented as a single integrated instrument for the advice and consent of the U.S. Senate, and require only one two-thirds vote of approval. ${ }^{121}$ On the other hand, if the United States were to ratify the CTBT relatively soon, and the Implementing Agreement were developed and presented only afterwards, in order to correct the deficiencies of article XIV and permit entry into force, then the U.S. president would face a difficult set of political choices. It would be audacious, indeed, to provide a "definitive signature," allowing the Implementing Agreement to become effective for the United States without a second Senate vote of advice and consent — but it may also be unappealing to have to fight the same ratification battle a second time for what is, essentially, the same treaty. ${ }^{122}$ Other participating states would also face their own calculations of domestic political and constitutional routes, but presumably some would be less punctilious about domestic processing, and able to take advantage of the expedited alternative.

Finally, as an institutional matter, the Implementing Agreement could address the treaty's organizational infrastructure, specifying that the current Preparatory Commission and Provisional Technical Secretariat will become-for the states that exercise the option to bring the CTBT and the Implementing Agreement into force among themselves-the full-fledged treaty organs. ${ }^{123}$ The CTBT Organization, consisting of the Conference of States Parties, the Executive Council, and the Technical Secretariat, would emerge as contemplated by article II of the treaty. ${ }^{124}$ Some of the current functions would be largely unaffected (e.g., the ongoing operations of the

121. This is the approach the United States adopted regarding the LoSC - the combined package of the original treaty, as modified by the Implementing Agreement, was submitted for a single exercise of Senate advice and consent. See Message from the President of the U.S. (Oct. 7, 1994), reprinted in United Nations Convention on the Law Of the SEA, with ANNEXEs, AND the AgReEment RELATING TO THE IMPLEMENTATION OF PART XI OF THE UNited NATIONS CONVENTION ON THE LAW Of THE SEA, With ANNEX, S. TREATy Doc. No. 103-39 (entered into force Nov. 16, 1994).

122. Conceivably, if the Implementing Agreement were developed subsequently, it could be handled as a "treaty executive agreement." Under that construct, the Senate, when providing its advice and consent to the original CTBT, would authorize the President to conclude the Implementing Agreement as a modification of it, without requiring a return to the legislative branch for a second endorsement. That route, however, seems politically unlikely here. See 11 U.S. DEPARTMENT OF STATE, Foreign AfFairs MANUAL 700, § 721.2.b(1) (2001).

123. The transition from the Preparatory Commission and Provisional Technical Secretariat to the permanent institutions of the CTBT could be tricky, especially since, as noted, the "original" CTBT that chartered the current provisional institutions is not precisely the document that will enter into force as the Implementing Agreement. It would be useful to have the U.N. General Assembly and the CTBT institutional bodies affirmatively endorse the "dual-hatting" and transition, as was done in the case of the LoSC. The text of the Implementing Agreement might not need to address this point explicitly; it could simply assume that the institutional infrastructure will be applied in full, as are all other aspects of the treaty, without any separate textual specification.

124. CTBT, supra note 1, art. II. 
International Monitoring System and the International Data Center would remain intact), but new functions, related to on-site inspections and settlement of disputes, would be initiated.

There is plenty of potential for confusion here, as the states that do not join the Implementing Agreement will continue to apply the treaty only provisionally and will regard the institutions as still being "preparatory," while other states will graduate to full legal effectiveness. Calculations of assessed dues obligations may become particularly problematic. But on the whole, even a sustained period of operation with such a bifurcated structure seems manageable.

\section{The Law of the Sea Convention Precedent}

There is one solid, contemporary, and prominent precedent for the approach outlined in this Article, coming from a very different body of international law. In 1982, culminating a decade of broadly multilateral, hotly-contested negotiations, the world concluded the Law of the Sea Convention (LoSC), regulating a wide range of human activities on, under and above the world's oceans. ${ }^{125}$ Most of the treaty turned out to be relatively uncontroversial, and was quickly accepted by the vast majority of seafaring states, even constituting new norms of progressive customary international law. ${ }^{126}$ But one topic proved persistently divisive: the provisions of Part XI of the treaty, devoted to establishing a new regime for mining of the deep sea bed, far beyond the shores of any state. ${ }^{127}$

The United States had fully participated in the evolution of the Convention, including endorsing the Part XI provisions for sharing, in some equitable fashion, the hard minerals of the deep sea bed as the "common heritage of mankind." "128 But the incoming Reagan administration in 1981 weighed the equities differently, and rejected key elements of Part XI, criticizing the mechanisms for allocating and controlling the resources, the

125. See generally United Nations Convention on the LAW of the SEA 1982: Vol. VI: A COMMENTARY, 3-54 (Myron Nordquist \& Satya N. Nandan eds., 2002) [hereinafter Nordquist]; LORI F. DAMROSCH \& SEAN D. MURPHY, INTERNATIONAL LAW CASES AND MATERIALS, 1355-60 (6th ed. 2014); see generally Warren Christopher, Letter of Submittal, September 23, 1994, reprinted in UNITED NATIONS CONVENTION ON THE LAW OF THE SEA, WITH ANNEXES, AND THE AGREEMENT RELATING to

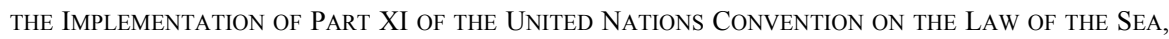
With ANNEX V, 103d Congress, 2d Sess., S. Treaty Doc. 103-39, (1994); DAVID ANDERSON, ModerN LAW OF THE SEA: SELECTED ESSAYS, 49-61 (2008) [hereinafter ANDERSON ESSAYS].

126. DAMROSCH \& MURPHY, supra note 125, at 1355-56, 1431; MARJORIE ANN BROWNE, CONG. RESEARCH SERV., IB95010, THE LAW OF THE SEA CONVENTION AND U.S. POLICY, 2 (2006) [hereinafter BROWNE 2006].

127. LoSC, supra note 4, Part XI; see generally Nordquist, supra note 125, at 64-159.

128. LoSC, supra note 4, art. 136; see generally, Nordquist, supra note 125, at 5-7, 39-48, 95-100; DAMROSCH \& MURPHY, supra note 125, at 1429-30. 
mining sites, the technology, and the financial proceeds. The United States thus declined to sign the LoSC and urged its allies and friends to reject it, too. ${ }^{129}$

Nonetheless, the LoSC proceeded to attract a trickle of signatures and ratifications from other states. After a decade, the $60^{\text {th }}$ ratification was deposited, triggering entry into force one year later, on November 16, 1994. ${ }^{130}$ At the same time, the ending of the Cold War and the accompanying widespread turn from communism toward capitalism underscored the importance of bringing the economically developed countries, especially the United States - the world's leading seafaring state, and the country most likely to engage in exploitation of the resources of the sea bed-into the LoSC regime. Efforts to revise Part XI therefore intensified in the early 1990s. ${ }^{131}$

However, the "front door" route to modifying the convention-a formal amendment of the relevant provisions - was blocked, due to the fact that the treaty had not yet entered into force (and even when the amendment provisions would become available, they were notably cumbersome and time-consuming, sure to generate delay in implementing the necessary changes). ${ }^{132}$ So a race then ensued, to try to modify the provisions of Part

129. See generally Nordquist, supra note 125, at 48-54; DAMROSCH \& MURPHY, supra note 125, at 1355-56, 1432; see Bernard H. Oxman, The 1994 Agreement and the Convention, 88 AM. J. OF INT'L L. 687, 688-89 (1994).

130. LoSC, supra note 4, art. 308; Chronological Lists of Ratifications of, Accessions and Successions to the Convention and Related Agreements, U.N. DIVISION FOR OCEAN AFF. \& THE LAW OF THE SEA, http://www.un.org/depts/los/reference_files/chronological_lists_of_ratifications.htm (last updated Sept. 23, 2016) (showing the progression of ratifications of the LoSC).

131. See Nordquist, supra note 125, at 57-59; DAMROSCH \& MURPHY, supra note 125, at 1356-57; see generally, ANDERSON ESSAYS, supra note 125, at 303-23.

132. The LoSC, supra note 4, contains several distinct provisions on amendments, each with its own applicability and impediments. Under art. 312, most treaty provisions are not subject to amendment until the treaty has been in force for ten years. Art. 313 contains expedited provisions for quicker amendment of certain aspects of the treaty if no party objects, but it is not applicable to deep sea mining. Art. 314 includes provisions for amendments related to deep sea mining, which might have been available for revising Part XI; activists assessed that use of these rules would have required considerable time and were of uncertain success. Art. 155 specifies procedures through which a review conference could amend the treaty. See also id. art. 311.6 (prohibiting amendments to the basic principle that the deep sea bed constituted "the common heritage of mankind"), and art. 316 (regarding the timing of the entry into force of amendments to the treaty); see generally ANDERSON ESSAYS, supra note 125, at 312, 332-33 (recounting analyses by negotiators and experts regarding possible routes for modifying the LoSC); James Harrison, MAKING THE LAW OF THE SEA: A STUDY IN THE DEVELOPMENT OF INTERNATIONAL LAW, 13134 (2011) 131-34; Bernard H. Oxman, The 1994 Agreement Relating to the Implementation of Part XI of the UN Convention on the Law of the Sea, in ORDER FOR THE OCEANS AT THE TURN OF THE CENTURY, 15 (Davor Vidas \& Willy Ostreng eds., 1999); David H. Anderson, The Mechanisms for Adjusting Part $X I$ and Their Relation to the Implementing Agreement, in 1994 RHODES PAPERS: ENTRY INTO FORCE OF THE LAW OF THE SEA CONVENTION 89, 94 (Myron H. Nordquist \& John Norton Moore eds.,1995); Nikos St. Skourtos, Legal Effects for Parties and Nonparties: The Impact of the Law of the Sea Convention, in 
$\mathrm{XI}$, via a subsequent agreement rather than an amendment, in the remaining months before the treaty entered into force. The device of an Implementing Agreement became the favored tool for preserving the accomplishments of the states that had already ratified the Convention, while incorporating the necessary changes to accommodate the United States. ${ }^{133}$ The negotiators undertook to retain some of the "common heritage of mankind" concept, while tempering the provisions for distributing the risks and benefits of deep sea bed mining. ${ }^{134}$

Remarkably, the diplomats succeeded in that high-stakes, fast-paced minuet, and the Implementing Agreement was concluded on July 28, 1994. The United States and others signed it and brought it into force provisionally on November 16, 1994, the same date that the main LoSC entered into force. $^{135}$ For the United States, the period of provisional application

1994 Rhodes PAPERS: ENTRY INTO ForCE OF THE LAW OF THE SEA CONVENTION 187, 190-93 (Myron H. Nordquist \& John N. Moore eds., 1995).

133. Kenneth Rattray, Assuring Universality: Balancing the Views of the Industrialized and Developing Worlds, in 1994 RHODES PAPERS: ENTRY INTO FORCE OF THE LAW OF THE SEA CONVENTION 55, 65 (Myron H. Nordquist \& John N. Moore eds., 1994) (reporting that negotiators "stumbled upon" the idea of an implementing agreement); HARRISON, supra note 132, at 90 (asserting that the 1994 document was the first treaty to be designated as an implementing agreement); Anderson, Mechanisms, supra note 132 (surveying options for modifying the LoSC); see generally Tullio Treves, The Agreement Completing the UN Law of the Sea Convention: Formal and Procedural Aspects, in 1994 RHODES PAPERS: ENTRY INTO FORCE OF THE LAW OF THE SEA CONVENTION 99, 99-103 (Myron H. Nordquist \& John N. Moore eds., 1995) (discussing the form of any modification).

134. Agreement Relating to the Implementation of Part XI of the United Nations Convention on the Law of the Sea of 10 December 1982, July 28, 1994, S. TREATY DoC. No. 103-39, 1836 U.N.T.S. 3 [hereinafter Implementing Agreement or LoSC Implementing Agreement]; E.D. Brown, The 1994 Agreement on the Implementation of Part XI of the UN Convention on the Law of the Sea: Breakthrough to Universality? 19 MARINE POL'Y 5, 9 (1995) (noting the negotiators' determination not to label the new document as an "amendment," although in reality it extended far beyond an "implementation" of the original treaty); ANDERSON ESSAYS, supra note 125, at 318, 332 (explaining that use of terms like "amend" or "replace" could have signified a renegotiation of the entire treaty, necessitating a new approval by national legislatures); $i d$. at 341-47 (assessing mechanisms for adjusting the LoSC); Louis B. Sohn, International Law Implications of the 1994 Agreement, 88 AM. J. INT'L LAW 696 (1994); HARRISON, supra note 132, at 91-93 (citing the view that the term "implementing agreement" was a euphemism for the word "amendment," and that the original provisions of Part XI were "disapplied"); Buga, supra note 106, at 4; Michael W. Lodge, The Deep Seabed, in OXFORD HANDBOOK OF THE LAW OF THE SEA, 16 n. 6 (Donald R. Rothwell et. al. eds., 2015) (suggesting that the Implementing Agreement "sidesteps" the question of whether it modifies or amends the original convention); Treves, supra note 133, at 104-05 (discussing the "thin line" between implementation and amendment). But see Henrique R. Valle, Adjustments to Part XI: United Nations Efforts (The Negotiation Process), in 1994 RHODES PAPERS: ENTRY INTO FORCE OF THE LAW OF THE SEA CONVENTION 47, 52 (Myron H. Nordquist \& John N. Moore eds., 1995) (insisting that the Convention has not been "amended").

135. The Implementing Agreement was provisionally applied from November 16, 1994, and entered into force on July 28, 1996. See Browne 2006, supra note 126, at 7; Brown, supra note 134, at 8; Michael C. Wood, International Seabed Authority: The First Four Years, 3 MAX PLANCK UNYB 173 (1999); Moritaka Hayashi, The 1994 Agreement for the Universalization of the Law of the Sea Convention, 27 OCEAN DEV. \& INT'L L. 31, 33-36 (1996); Rosenne, supra note 101, at 494-96; Treves, 
continued for only four years; when the Senate declined to provide advice and consent, the United States stood (and still stands) entirely outside the LoSC regime. ${ }^{136}$ For 168 other states, the modified structure is now in place, and has been operational for more than two decades. ${ }^{137}$

The LoSC Implementing Agreement (unlike that proposed in this Article for CTBT) is lengthy and complex - the altered arrangements for the new mining regime require many pages of specifications to unravel detailed aspects of the original Part XI. ${ }^{138}$ Procedurally, however, there are important similarities to what is proposed here, especially regarding the mechanism for affording each participating state an expedited or simplified procedure for adopting the Implementing Agreement, rather than requiring the usual laborious steps of signature and ratification. The remainder of this section compares the two approaches. ${ }^{139}$

supra note 133, at 111-15.; see generally Nordquist, supra note 125, at 57-63; DAMROSCH \& MURPHY, supra note 125 , at $1357-58,1432$.

136. Lists of Ratifications, supra note 130. The United States applied both the Convention and the Implementing Agreement on a provisional basis for four years starting on November 16, 1994. See generally, BROWNE 2006, supra note 126, at 8-9; DAMROSCH \& MURPHY, supra note 125, at 1357-58; Nordquist, supra note 125, at 63; Sohn, supra note 134; Jonathan I. Charney, U.S. Provisional Application of the 1994 Deep Seabed Agreement, 88 AM. J. INT'L L. 705 (1994).

137. Lists of Ratifications, supra note 130; see generally, Wood, supra note 135. For comparison, note that states have also concluded another implementing agreement to the LoSC, to deal with conservation and management of certain stocks of fish, Agreement for the Implementation of the Provisions of the United Nations Convention on the Law of the Sea of 10 December 1982, Relating to the Conservation and Management of Straddling Fish Stocks and Highly Migratory Fish Stocks, August 4, 1995, 34 I.L.M. 1542 (1995). The 1995 Implementing Agreement is more free-standing than the 1994 Implementing Agreement and does not alter the original treaty; unlike the agreement relating to Part XI, a state may join the fish stocks agreement without joining the LoSC. HARRISON, supra note 132, at 10308 .

138. Among other alterations, the Implementing Agreement revised the decision-making power structure of the treaty's organs, to enhance the authority of the United States; removed production limits that would have inhibited deep sea mining; mitigated the requirements for transferring private mining technology to the treaty's mining arm; and reduced fees charged to miners. See BROWNE 2006, supra note 126, at 6-8; Oxman, supra note 129, at 695; Brown, supra note 134, at 10-15; see D.H. Anderson, Resolution and Agreement Relating to the Implementation of Part XI of the UN Convention on the Law of the Sea: A General Assessment, 55 ZAÖRV, 275, 284-88 (1995), http://www.zaoerv.de/55_1995/55_1995_2_a_275_289.pdf; Fact Sheet, How the Law of the Sea Convention Was Fixed to Address President Reagan's Concerns, U.S. DeP'T OF STATE, (Feb. 15, 2012), https:/www.state.gov/e/oes/lawofthesea/factsheets/183994.htm [https://web.archive.org/web/ 20170113150337/https://www.state.gov/e/oes/lawofthesea/factsheets/183994.html]; Wood, supra note 135.

139. See Gabriella Venturini, Test Bans and the Comprehensive Test Ban Treaty Organization, in NUCLEAR NON-PROLIFERATION IN INTERNATIONAL LAW 133, 151 (Jonathan L. Black-Branch \& Dieter Fleck eds., 2014) (positing an instrument modeled on the LoSC Implementing Agreement as a mechanism for modifying the CTBT to permit its entry into force, but suggesting that the circumstances contributing to success in the LoSC instance were unique, and concluding that it is "highly unlikely" that CTBT states would be inclined to undertake such a complex process). 


\section{Similarities.}

Both the LoSC Implementing Agreement and the proposed CTBT Implementing Agreement give each state some choices. A state can join the revision document simply by signing, not subject to ratification; by signature subject to a twelve-month waiting period; or by signature followed by ratification. ${ }^{140}$

In the LoSC version, the middle option, allowing up to one year's waiting period before joinder, is available only to a state that had already deposited its instrument of ratification (or the equivalent) for the original LoSC. In my proposal, that path is available for all states. ${ }^{141}$ For the LoSC Implementing Agreement, two states (Belize and Kenya) used the "definitive signature" mechanism, and sixteen others adopted the "simplified procedure" to join within one year, without an act of ratification. ${ }^{142}$

In both the LoSC and CTBT versions, a state is prevented from joining only the Implementing Agreement; if it wishes to adhere, it must previously or simultaneously accept the original treaty, too. ${ }^{143}$ That limitation is more important for the LoSC, where a state might conceivably have wanted to affiliate with only the revised deep sea bed mining provisions, while not joining the rest of the treaty. In the case of CTBT, in contrast, there is no substantive difference between the content of the original treaty and the Implementing Agreement. Still, the prospect of creating two classes of parties to either treaty is problematic, at least as a formal matter: some states will have ratified only the original document, while others will have consented to both.

Also, both instruments specify some threshold number of ratifications required before the Implementing Agreement can enter into force. For LoSC, participation by forty states is required, with the further qualification

140. LoSC Implementing Agreement, supra note 138, art. 4.3; proposed CTBT Implementing Agreement, infra Part IV, art. I.1; Hayashi, supra note 135, at 32-33; Brown, supra note 134, at 6-7; HARRISON, supra note 132, at 94; Treves, supra note 133, at 109-10. The United States signed subject to ratification. Commentary-The 1982 United Nations Convention on the Law of the Sea and the Agreement on Implementation of Part XI, reprinted in UNITED NATIONS CONVENTION ON THE LAW OF THE SEA, WITH ANNEXES, AND THE AGREEMENT RELATING TO THE IMPLEMENTATION OF PART XI OF THE United NATIONS CONVENTION ON THE LAW OF THE SEA, with ANNEX 76, 103d Congress, 2d Sess., S. Treaty Doc. 103-39, (1994); ANDERSON ESSAYS, supra note 125, at 319-20.

141. Compare LoSC Implementing Agreement, supra note 134, art. 5.1 with proposed CTBT Implementing Agreement, infra, Part IV, art. I.1 see also Treves, supra note 133, at 107-110.

142. U.N. DiV. FOR OCEAN AFFAIRS \& THE LAW OF THE SEA, OFF. OF LEGAL AFFAIRS, LAW OF THE SEA BUll. No. 89, at 1 (2015) (including chart recapitulating status of the Convention and Implementing Agreement as of November 30, 2015); Hayashi, supra note 135, at 33.

143. Compare LoSC Implementing Agreement, supra note 134, art. 4.2 with proposed CTBT Implementing Agreement, infra Part IV, art. I.4; see also Harrison, supra note 132, at 93-94 (emphasizing that the LoSC and the Implementing Agreement are to be construed as a single instrument). 
that at least seven of those states must come from a designated group of "pioneer investors" in deep sea mining, and that at least five of those must qualify as being economically developed. ${ }^{144}$ In my proposal, the threshold is lower, requiring only twenty states, without any specialized roster of essential participants. ${ }^{145}$

Finally, as a political matter, the execution of the novel LoSC process benefited greatly from the explicit endorsements by the U.N. General Assembly and the LoSC administrative bodies. ${ }^{146}$ The CTBT and its Implementing Agreement should follow that avenue, too, although that subject is not addressed explicitly in these documents.

\section{Differences}

The LoSC Implementing Agreement purports to prohibit a country from henceforth joining the original LoSC without accepting the Implementing Agreement, too. This provision is designed to prevent further worsening of the paradox of having some states become party to both the first and second documents while others affiliate with only the first. It is less important for the CTBT, and is omitted from this Article's proposed draft text, because, again, there is no substantive difference between the two test ban accords, and because my Implementing Agreement would still afford each state the option of insisting upon the difficult entry into force provisions of the original article XIV, if it so chose. ${ }^{147}$

Moreover, there is something of a legal puzzle about whether a subsequent treaty (such as an implementing agreement) can validly foreclose states' options regarding joining an earlier treaty. If the original instrument would otherwise, by its own terms, remain open for signature or accession by additional states, it is not clear how a later document crafted and signed by other states can terminate that option. In any event, that problematic

144. LoSC Implementing Agreement, supra note 134138, art. 6.1; Sohn, supra note 134, at 698; see generally Anderson, Mechanisms, supra note 133, at 282 (identifying the key pioneer investing states); Hayashi, supra note 135, at 37; ANDERSON ESSAYS, supra note 125, at 320 (explaining that one reason for specifying the participation of wealthy pioneer investors was to ensure that the developed countries would be available to provide the necessary financial support for the treaty's infrastructure).

145. Compare LoSC Implementing Agreement, supra note 134, art. 6.1 with proposed CTBT Implementing Agreement, infra Part IV, art. II.4.

146. G.A. Res. 48/263 (July 28, 1994) (endorsing unanimously the Implementing Agreement);

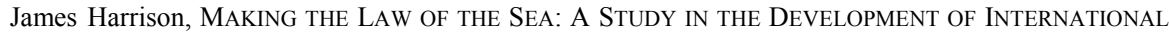
LAW, 86-90 (2011) (emphasizing the role that the United Nations General Assembly played in endorsing and legitimating the effort to revise the LoSC).

147. Compare LoSC Implementing Agreement, supra note 134, art. 4.1 with proposed CTBT Implementing Agreement, infra Part IV, art. I. 
aspect of the LoSC Implementing Agreement is not carried forward in the CTBT variant. ${ }^{148}$

It should be noted that the proffered CTBT Implementing Agreement multiplies, not restricts, states' options. Each country would be afforded the two-step choice: a) whether to join the Implementing Agreement at all; and b) if it does join, whether to exercise the option to waive the strict CTBT entry into force restrictions. Moreover, each party has the further choice to express its consent to either of those actions: a) immediately; b) with effect after a one year delay; or c) only after ratification. ${ }^{149}$ In addition, a state would be permitted to change its mind, altering its initial preferences in light of subsequent events.

It is also noteworthy that a state that decides to join the draft CTBT Implementing Agreement would be required to ratify the original CTBT first (or simultaneously), even if, after doing so, it declined to exercise the waiver operation and bring the CTBT obligations into force for itself immediately (or after one year). Therefore, an Annex 2 state in such a situation would count toward the fulfillment of article XIV, bringing eventual formal entry into force of the CTBT one step closer. This might, for some states, be an attractive mechanism for expressing support for the treaty without yet incurring immediate additional obligations under it.

For each treaty, the messiness will persist in creating two groups of parties, possessing overlapping but not identical sets of obligations. ${ }^{150}$ But

148. As a practical matter, the newer instrument could be said to "spoil" the original, and the depositary could be instructed not to accept any new signatures or instruments of ratification of the original treaty that did not simultaneously embrace the newer. But VCLT, supra note 64, art. 40.5 contemplates that, in general, a state joining an amended treaty could elect not to accept the amendment. Compare with LoSC Implementing Agreement, supra note 134, art. 4.1. See Brown, supra note 134, at 7 (calling this aspect of the LoSC Implementing Agreement "surprising"); Treves, supra note 133, at 10809; Hayashi, supra note 135, at 32 (discussing the operation of the "principle of simultaneous acceptance" of the related agreements); see ANDERSON ESSAYS, supra note 125, at 346 (asserting that the LoSC Implementing Agreement takes into account the position of states that had previously ratified the original treaty).

149. International practice offers several precedents of treaties that are structured to afford states multiple options regarding the legal obligations they assume. The Convention on Certain Conventional Weapons, for example, consists of a main treaty that is basically just a chapeau, under which is a series of protocols dealing with specific weapons (such as blinding lasers, land mines, and incendiaries) that each party can elect to join a la carte. See CCW, supra note 88. Likewise MARPOL 73/78, discussed infra, contains a series of optional annexes dealing with particular sources of marine pollution; when (or after) joining the main treaty, each party can determine which of these annexes to accept.

150. In fact, in both the LoSC and CTBT instances, there are more than simply two groups of relevant states. A state may ratify, sign but not ratify, or not sign each of the two instruments (the original treaty and the relevant implementing agreement), and the network of overlapping and inconsistent rights and obligations could become quite complex. The most fundament dichotomy would be between states that have joined only the original agreement vs. states that have joined both the original and the implementing agreement. 
that "duality of regimes" problem is much more extensive for the LoSC than for the CTBT. ${ }^{151}$ In the LoSC case, a state that had joined the original treaty but not the Implementing Agreement could, in principle, insist upon fulfillment of its original bargain, unimpaired by the subsequent accord reached by only some of its initial treaty partners. That state, in theory, could demand that the original "common heritage of mankind" mechanism for mining be implemented, regardless of how it had been modified inter se by others. As of September 2016, some eighteen countries are in that situation; ${ }^{152}$ in practice they have not pressed those claims, and the overall treaty regime could not implement both sets of relationships in any meaningful fashion. In practice, only the Implementing Agreement is being effectuated for deep seabed mining, but the legal basis for that accommodation is uneasy. ${ }^{153}$

For the CTBT, the disconnect arises from the fact that a state that had joined only the original treaty would be subject only to its provisional application - it would owe support to the IMS and the other aspects of the monitoring system, but would not have committed itself to participate in the on-site inspection or dispute-resolution mechanisms. Honoring those additional features would be a burden only for the states that have voluntarily accepted the Implementing Agreement. But any "conflict" between the rights and obligations of the two groups of states is relatively quite muted. ${ }^{154}$

151. As noted, in the case of CTBT, the proposed Implementing Agreement is a distinct instrument which incorporates the text of the original treaty (except for article XIV); it is the Implementing Agreement, rather than the original CTBT, that will initially enter into force. In contrast, in the LoSC case, both the original treaty and the Implementing Agreement entered into force almost simultaneously.

152. LAW OF THE SEA BULL. 89, supra note 142; Lists of Ratifications, supra note 130. This diverse group includes Bahrain, Bosnia and Herzegovina, the Democratic Republic of the Congo, Dominica, Egypt, Iraq, and Somalia, among others. See Treves, supra note 133, at 115-16 (examining the conflict if some parties to the original LoSC do not join the Implementing Agreement); HARRISON, supra note 132 , at 94-95.

153. Lodge, supra note 134, at 16 n. 8; Buga, supra note 106, at 5; Brown, supra note 134, at 18; Int'l Seabed Auth., Assembly, Report of the Secretary-General of the International Seabed Authority Under Article 166, ๆ 4, of the United Nations Convention on the Law of the Sea, at 2, ๆ 5, ISBA/16/A/2 (Mar. 8, 2010) (noting that even those states that have not joined the Implementing Agreement nonetheless necessarily participate in the work of the treaty bodies based on that Implementing Agreement; if those states were to join the Implementing Agreement, it "would remove an incongruity that currently exists for those States."); see Jutta Brunnee, Treaty Amendments, in THE OXFORD GUIDE TO TREATIES 347, 364 (Duncan B. Hollis ed., 2012) (observing that states that became party to the original LoSC but not to the Implementing Agreement "will find it increasingly difficult to maintain their original interpretation of Part XI."); HARRISON, supra note 132, at 95-97; R.R. CHURCHILL AND A.V. LOWE, THE LAW OF THE SEA 20-21 (3rd ed. 1999). The unanimous U.N. General Assembly resolution of support for the Implementing Agreement indicates strong global support for the process, even among states that have not affirmatively acted to join the Implementing Agreement; perhaps that tacit acquiescence can amount to a waiver of any potential objection to the process.

154. In one sense, a state that joins only the original CTBT while others create the Implementing Agreement would lose its "right" to have the treaty not come into force for anyone until all forty-four 


\section{E. Other Precedents}

Finally, it should be noted that in addition to the LoSC, international legal practice has had other occasions to wrestle with the question of a treaty that suffers from inadequate support for entry into force, but that should not be wholly consigned to the scrap heap. For example, the 1973 International Convention for the Prevention of Pollution from Ships (MARPOL) is a leading instrument protecting the maritime environment. ${ }^{155}$ The 1973 version of the treaty specified that it would enter into force when ratified by fifteen states with a combined merchant fleet representing fifty percent of the world's gross shipping tonnage. It also mandated that in order to join the treaty, a state would have to accept both of its mandatory annexes (dealing, respectively, with pollution by oil, and by other chemicals). ${ }^{156}$

By 1976, the treaty had been ratified by only three states (Jordan, Kenya and Tunisia), representing less than one percent of the world's merchant shipping, and the prospects for securing the necessary additional ratifications seemed bleak. A spate of catastrophic tanker accidents then underscored the urgency of undertaking meaningful, prompt action. ${ }^{157}$ States accordingly

Annex 2 states have ratified. That state can, of course, still ensure that the treaty does not come into force for itself until art. XIV is satisfied, but it would lose its ability to hold hostage the entry into force for all other states. In this regard, it is noteworthy that the CTBT negotiators had contemplated, but rejected, inserting this type of "waiver" provision into article XIV of the original treaty. So a state that clings to the original version of the treaty may be said to suffer a compromise of part of its original bargain, which suggests some possible tension with arts. 34 and 35 of the VCLT, supra note 64 (asserting that a treaty generally does not create rights or obligations for states that do not join). In this instance, that expectation is not a right that should be protected; it is not illegitimate for other states to depart from it by a subsequent Implementing Agreement operational only among themselves. See VCLT, supra note 64, arts. 30, 41 (noting that a party to an earlier treaty (or to an unamended treaty) does not lose treaty rights when other parties conclude a subsequent agreement on the same subject matter (or an amendment to the original treaty)). Calculating the dues of CTBT parties would become more complex under this initiative; states for which the treaty was in force would be obligated to support the entire treaty structure, including the costs of on-site inspection operations, while the states that were bound only by the commitment to provisional application would pay less.

155. International Convention for the Prevention of Pollution from Ships (MARPOL 73/78), November 2, 1973, 12 I.L.M. 1319 (1973) [hereinafter MARPOL 73/78], modified by Protocol of 1978 Relating to the International Convention for the Prevention of Pollution from Ships, February 17, 1978, 1341 U.N.T.S. 3, 17 I.L.M. 546 (1978) [hereinafter 1978 MARPOL Protocol] [collectively referred to hereinafter as MARPOL 73/78]; International Convention for the Prevention of Pollution from Ships (MARPOL), INT'L MARITIME ORG., http://www.imo.org/en/About/Conventions/ListOfConventions/ Pages/International-Convention-for-the-Prevention-of-Pollution-from-Ships-(MARPOL).aspx (last visited Jan. 31, 2017); Edgar Gold, GARD HANDBOOK ON MARINE POLLUTION, 68-70, 98-122 (2d ed. 1998); Douglas Brubaker, Marine POLlution AND INTERNATIONAL LAW: PRINCIPLES AND PRACTICE, 122-27 (1993).

156. MARPOL 73/78, supra note 155, arts. 1, 14, 15, Annex I, Annex II.

157. MARPOL73-78: Brief History - List of Amendments to Date and Where to Find Them, INT'L MARITIME ORG. (on file with the Duke Journal of Comparative \& International Law); GOLD, supra note 155, at 40; Brubaker, supra note 155. 
negotiated a 1978 protocol, which modified, expanded, and absorbed the original agreement. That protocol - effectively an implementing agreement, under a different moniker ${ }^{158}$ — specified that a state need affiliate only with a modified version of Annex 1, and provided an additional several years for states to negotiate revisions to Annex 2 and adapt to its requirements. ${ }^{159}$

States were permitted to join the resulting combined package-a kludge generally treated as a single instrument and referred to as MARPOL 73/78via signature alone or via signature followed by ratification. ${ }^{160}$ That package entered into force in 1983; it has subsequently been modified several more times, via the usual amendment procedures (and via an additional 1997 protocol), and has attracted 155 parties. ${ }^{161}$

The 1993 START II Treaty offers a somewhat similar case study in a bilateral context. ${ }^{162}$ There, after the agreement had been negotiated and signed, the U.S. Senate provided its advice and consent to ratification on January 26, 1994. However, the Russian Duma did not vote affirmatively until April 14, 2000, leaving too little time to meet the treaty's deadlines (in 2001 and 2003) for accomplishing the planned destruction of specified nuclear weapons. Anticipating this problem, the United States and Russia therefore concluded a protocol on September 26, 1997, that extended some of the deadlines to December 31, 2004 or December 31, 2007. ${ }^{163}$ The

158. States working in 1994 to modify the original LoSC via the mechanism of an implementing agreement were well aware of the MARPOL 73/78 precedent, but chose different vocabulary. ANDERSON ESSAYS, supra note 125, at 318.

159. 1978 MARPOL Protocol, supra note 155, arts. I, II; Rosenne, supra note 101, at 496 n. 16; Gini Mattson, MARPOL 73/78 and Annex I: An Assessment of Its Effectiveness, 9 J. INT'L WILDLIFE L. \& POL'Y 175, 180 (2006); see Andrew Griffin, MARPOL 73/78 and Vessel Pollution: A Glass Half Full or Half Empty?, 1 IND. J. GLOBAL LEGAL STUD. 489, 490-91 (1994).

160. MARPOL 73/78, supra note 155, art. IV; Yoshio Sasamura, Implementation of MARPOL 73/78, in International Oil SPILl CONFEREnCE ProceEdings 121-25 (Feb. 1985), http://ioscproceedings.org/doi/abs/10.7901/2169-3358-1985-1-121; Ilian Djadjev, How to Comply with MARPOL 73/78 (May 15, 2015), https://papers.ssrn.com/sol3/papers.cfm?abstract_id=2617379. Uruguay was the only state to join via signature alone. Int'l Maritime Org., Status of Multilateral Conventions and Instruments in Respect of Which the International Maritime Organization or Its Secretary-General Performs Depositary or Other Functions, 106, 107, 111 (Jan. 11, 2017), http://www.imo.org/en/About/Conventions/StatusOfConventions/Documents/Status\%20$\% 202017$. docx.pdf.

161. IMO Brief History, supra note 157 . The combined treaty now embraces six technical annexes. Id.

162. Treaty Between the United States of America and the Russian Federation on Further Reduction and Limitation of Strategic Offensive Arms (the START II Treaty), U.S.-Russ., Jan. 3, 1993, S. TREATY. DoC. 103-1, http://www.state.gov/t/avc/trty/102887.htm.

163. Protocol to the Treaty Between the United States of America and the Russian Federation on Further Reduction and Limitation of Strategic Offensive Arms of January 3, 1993, U.S.-Russ., Sept. 26, 1997, https://fas.org/nuke/control/start2/text/index.html ; see also Strategic Arms Reduction Treaty II Chronology, FED’N AM. SCIENTISTS, https://fas.org/nuke/control/start2/docs/strt-chr.htm. 
protocol was not effectuated as an "amendment" to START II, because until that treaty entered into force, its amendment provisions were not operational; the protocol was, instead, another version of an implementing agreement. Due to the protocol's alteration of the destruction schedule, START II required a second vote of approval by the legislatures in both countries, which did not occur, so neither the treaty nor the protocol ever became legally functional. ${ }^{164}$

\section{THE PROPOSED TEXT OF THE CTBT IMPLEMENTING AGREEMENT}

This part of the Article puts into practice the principles and propositions adduced above, by offering a draft text of the CTBT Implementing Agreement. It is not intended as a complete treaty, ready for state signature, but it does provide a vehicle for illustrating the operation of the strategies outlined in the Article, and for identifying some of the options that negotiators would have to resolve. ${ }^{165}$ Working through the legal text of such a proposal is always more illuminating-for the drafter and the reader alike-than stopping at a more generic level of argumentation and analysis. $^{166}$

\section{Draft Text: \\ Implementing Agreement \\ for the Comprehensive Nuclear-Test-Ban Treaty}

$$
\text { Preamble } e^{167}
$$

The Parties to this Implementing Agreement,

Recognizing the important contribution of the 1996 Comprehensive NuclearTest-Ban Treaty as an effective measure toward nuclear disarmament and against the proliferation of nuclear weapons, ${ }^{168}$ 61.

164. See, GRAHAM AND LAVERA, supra note 12 , at 889, 1165; see, Michie, supra note 64 , at 360-

165. This Article does not address the important question of what forum should be used to negotiate the proposed Implementing Agreement. There may be several alternative venues available, and the choice among them could carry both legal and political implications, but is beyond the scope of the current work.

166. See, e.g., Anastassov, supra note 53, at 96 (presenting a proposed draft text of an optional protocol on provisional application of portions of the CTBT). For ease of reference, this document will be cited as "proposed CTBT Implementing Agreement," or (if the context is clear in differentiating it from the LoSC Implementing Agreement, supra note 134) as "Implementing Agreement."

167. A treaty preamble does not ordinarily include legally binding obligations, but can be useful in interpreting the object and purpose of the document. See Jonas, supra note 56, at 1038; Tabassi, supra note 88 , at 317 .

168. This paragraph is based on the CTBT preamble, third paragraph, supra note 1. 
Wishing to facilitate universal participation in the Comprehensive NuclearTest-Ban Treaty and to promote its prompt entry into force, ${ }^{169}$

Stressing the importance of each state's sovereign decision-making regarding the procedures and timing for effectuating its participation in the Comprehensive Nuclear-Test-Ban Treaty, and desiring to increase states' options, ${ }^{170}$

Grateful for the success of provisional application of the Comprehensive Nuclear-Test-Ban Treaty and the enormous contributions of the Preparatory Commission for the Comprehensive Nuclear-Test-Ban Treaty Organization, the Provisional Technical Secretariat, and the Executive Secretary, and desiring to make their accomplishments permanent, ${ }^{171}$

Have agreed as follows,

\section{Article I}

1. Any state ${ }^{172}$ may express its consent to be bound by this Implementing Agreement by:

a. definitive signature, effective immediately, ${ }^{173}$

b. signature, effective after one year; or

c. signature followed by ratification.

2. Any state that initially selects option b in article I.1 may switch to option a. or option c., by notification to the Depositary prior to the expiration of the one year period.

3. Any state that initially selects option c. in article I.1 may switch to option a. or option b., by notification to the Depositary prior to the deposit of its instrument of ratification.

169. This paragraph is based on the LoSC Implementing Agreement, sixth preambular paragraph, supra note 134.

170. This paragraph acknowledges that the proposed Implementing Agreement cannot compel states to join the effort to revise the CTBT or to depart from holding out against entry into force of the CTBT. Instead, the concept is to provide each state with additional options regarding both substance and procedure that it might decide to pursue in the exercise of its sovereign decision-making.

171. This paragraph constitutes an acknowledgement of the contributions of the provisional CTBT organization and personnel, and their success in preparing for entry into force of the treaty.

172. This version does not confine the use of the simplified or expedited procedure to only those states that had previously ratified the original treaty, as the LoSC Implementing Agreement does.

173. In this context, the consent would be given immediately, but would not become operational until after the Implementing Agreement has received consent from sufficient other states, and then the passage of one year, pursuant to art. I.6. 
4. No state may express its consent to be bound by this Implementing Agreement $^{174}$ unless it has previously or simultaneously deposited its instrument of ratification or accession ${ }^{175}$ to the Comprehensive NuclearTest-Ban Treaty. ${ }^{176}$

5. This Implementing Agreement shall be open for signature indefinitely. ${ }^{177}$

6. This Implementing Agreement shall enter into force for consenting states one year ${ }^{178}$ after the twentieth state expresses its consent to be bound by it. ${ }^{179}$ Thereafter, it shall enter into force for each additional consenting state upon the effective date of its expression of consent.

7. In the event of any inconsistency between this Implementing Agreement and the Comprehensive Nuclear-Test-Ban Treaty, the provisions of this Implementing Agreement shall prevail. ${ }^{180}$

\section{Article II}

1. When a state expresses its consent to be bound by this Implementing Agreement, it shall declare that the terms of the Comprehensive NuclearTest-Ban Treaty other than article XIV.1 will enter into force for it:

174. As drafted, this provision would allow a state to sign the Implementing Agreement even if it has not yet signed and ratified the CTBT, if it signs the Implementing Agreement subject to ratification; the state could not then proceed to ratify the Implementing Agreement until it had ratified the CTBT, too. An alternative would be to specify that a state may not even sign the Implementing Agreement until it had previously (or simultaneously) ratified the CTBT. The current version would allow a signature by, for example, a state in which the executive branch was favorably disposed to the CTBT and wanted to take a step toward the Implementing Agreement, even if it could not yet persuade the legislative branch to support ratification of the CTBT.

175. This provision means that any state that joins the Implementing Agreement will have also joined the CTBT; for a state listed in Annex 2, it will therefore count toward satisfying the requirements of art. XIV.1, even if it elects not to waive the requirement that the provisions of the CTBT will become operational for it only when all forty-four designated states have joined.

176. In the LoSC version of this process, there is a parallel provision prohibiting a state from now joining the original treaty without simultaneously accepting the Implementing Agreement. That restriction is unnecessary here (since there would be little point to joining this Implementing Agreement without joining the CTBT) and because it is legally problematic for a subsequent treaty to prevent states from joining an earlier one.

177. Many treaties are open for signature for only a limited period of time; after that point, a state seeking to join the treaty does so via depositing an instrument of accession. The option presented here is a bit simpler.

178. The Implementing Agreement could shorten this period to 180 days, as many treaties (including the CTBT) do.

179. A low number of state acceptances is appropriate here, since each state still retains options regarding the timing of the effectuation of its legal obligations to refrain from conducting nuclear tests. Alternatively, the Implementing Agreement could also require that some specified states (such as the five permanent members of the U.N. Security Council) would have to join before the Implementing Agreement becomes effective for any state.

180. This paragraph is based on the LoSC Implementing Agreement, supra note 134, art. 2.1. 

a. immediately; ${ }^{181}$
b. after one year; or
c. pursuant to the terms of article XIV.1 of the Comprehensive Nuclear-Test-Ban Treaty.

2. Any state that initially selects option b. in article II.1 may switch to option a. or option c., by notification to the Depositary prior to the expiration of the one year period.

3. Any state that initially selects option c. in article II.1 may switch to option a. or option b., by notification to the Depositary at any time.

4. The terms of the Comprehensive Nuclear-Test-Ban Treaty other than article XIV.1 shall enter into force for all states that have accepted its entry into force one year ${ }^{182}$ after twenty states ${ }^{183}$ have accepted it. ${ }^{184}$

5. The Comprehensive Nuclear-Test-Ban Treaty Organization shall become operational on the date the Treaty enters into force. ${ }^{185}$

\section{Article III}

1. The Secretary-General of the United Nations shall be the depositary of this Implementing Agreement. ${ }^{186}$

2. The Arabic, Chinese, English, French, Russian, and Spanish texts of this Implementing Agreement are equally authentic. ${ }^{187}$

In witness whereof, the undersigned, being duly authorized to that effect, have signed this Implementing Agreement.

181. In this context, the consent would be given immediately, but would not become operational until after the Implementing Agreement has received consent from sufficient other states, and then the passage of one year, pursuant to art. II.4.

182. The Implementing Agreement could shorten this period to 180 days, as many treaties (including the CTBT) do.

183. A low number of state acceptances is appropriate here, since each state still retains options regarding the timing of the effectuation of its legal obligations. Again, the Implementing Agreement could require that some specified states (such as the five permanent members of the U.N. Security Council) would have to join before the CTBT becomes effective for any state.

184. The Implementing Agreement could omit this provision altogether, allowing the CTBT to become operational for each state, one by one, on the dates they individually accept it.

185. This provision may be unnecessary, since the concept is that all aspects of the CTBT will become operational for states accepting the Implementing Agreement. But it may be useful to call out the institutional infrastructure for special mention here.

186. This is a standard provision in international agreements, such as in the LoSC Implementing Agreement, supra note 134, art. 9.

187. This is a standard provision in international agreements, such as in the LoSC Implementing Agreement, supra note 134, art. 10. 
Done at XXX, on this (date).

[National signatures]

\section{CONCLUSION}

What are the key lessons from this analysis of an alternative mechanism for effectuating the CTBT? First, it is apparent that going through the "front door"- securing the necessary ratifications in order to bring the treaty into effect as originally drafted-would be preferable. The negotiators had a valid point in insisting that participation by all forty-four identified states would provide the strongest basis for ensuring that the CTBT's benefits and burdens would be shared equally and simultaneously by all the most essential participants in global nuclear security affairs.

However, more than twenty years of frustrated experience has made manifest that this preferred strategy simply will not succeed in any foreseeable future. There is little sign that the eight Annex 2 holdouts will soon change course, and even if some of them did, it requires truly magical thinking to suppose that rogue regimes will acquiesce to the wishes and needs of the rest of the global community. At the same time, the imperative for effectuating the CTBT has become only more urgent. Both for its contribution to interdicting future developments in a nuclear arms race and as an indispensable element in preserving the global consensus underpinning the nuclear nonproliferation regime, CTBT is needed more now than ever. The world has tried to "work through" the mess created by article XIV for two decades; now it's time to try to "work around" it.

Some might suggest that the device of an Implementing Agreement offers such a complicated, novel scheme that it would be simpler just to start the negotiations all over again, and draft a new and improved CTBT, one without the fatal disability of the Annex 2 unanimity requirement. But "starting from scratch" is both unnecessary and unwise here. We should not simply throw away the 166 ratifications that have been assembled so laboriously, nor should we dispose of all that has been accomplished by the two decades of salutary operation and hard lessons learned by the treaty's Preparatory Commission and Provisional Technical Secretariat.

The Implementing Agreement offers participating countries the option to proceed more nimbly to modify the article XIV defect; it permits them to build upon the accomplishments achieved to date, and dodge the burden of undertaking a second ratification effort. Some states, of course, will not exercise that shortcut option - they would again follow the "standard" path of signature followed by ratification, pursuant to whatever national mechanism was required for authorizing each step. But the Law of the Sea Convention precedent illustrates that at least some states will expedite the 
process, bringing the revised package of international agreements into force more swiftly and easily.

Not just incidentally, the Implementing Agreement also offers an advantage in confining the revision process to the single issue of article XIV, rather than risking re-opening the test ban treaty negotiations more generally. If the world were to create a more open-ended "second look" at the CTBT, who knows what other matters might be put onto the table? The three years of formal CTBT negotiations (not to mention the four decades of background efforts that preceded them) were difficult and contentious; at many points, it was far from clear that success would be achieved. Rather than revisiting all that trauma, the world should now focus on the one aspect of the original treaty that truly needs fixing: its cumbersome entry into force standards. ${ }^{188}$

Another plausible alternative might be to strengthen the existing provisional status of the test ban and its supporting organizational infrastructure. ${ }^{189}$ For example, the CTBTO might be re-calibrated as a "permanent" international institution, shedding the words "preparatory" and "provisional" from its titles. Likewise, the scope of the current provisional application could be expanded-just as the signatories had crafted the current range of partial implementation tasks, they could now agree to enlarge it, such as to operationalize the treaty's on-site inspection apparatus and its dispute-resolution modalities. ${ }^{190}$ In some instances (the 1947 General Agreement on Tariffs and Trade (GATT) is the most prominent illustration)

188. Similar considerations arose during the process of revising the Law of the Sea Convention in 1994, leading to a preference for an Implementing Agreement that would address only the single issue of revising Part XI, rather than risk re-opening the entire Convention for additional possible modification and unraveling. See Anderson, supra note 132, at 277; see ANDERSON ESSAYS, supra note 125, at 277.

189. In principle, the states that created the existing program of provisional operation could agree to enlarge its scope, edging closer to the equivalent of formal entry into force. Alternatively, some subset of signatories could agree to go further inter se, even if others were reluctant. See generally Michie, supra note 64; Dalton, supra note 65; D. Anderson, Legal Implications of the Entry into Force of the U.N. Convention on the Law of the Sea, 44 INT'L \& COMP. L. Q. 313 (1995); Lorand Bartels, Withdrawing Provisional Application of Treaties - Has the European Union Made a Mistake?, 1 CAMBRIDGE J. INT'L \& COMP. L. 112-118 (2012).

190. Frank Barnaby, Paul Rogers \& Jack Mendelsohn, CONSTRUCTIVE APPROACHES TO LiMITING THE SPREAD OF NUCLEAR WEAPONS: SOME PROPOSALS FOR GOVERNMENT ACTION 13-15 (Apr. 2004), http://www.oxfordresearchgroup.org.uk/sites/default/files/nonproliferation.pdf (proposing to expand the CTBT's provisional application); Venturini, Prepcom at 20, supra note 65, at 350; Anthony Aust, et.al. A New Look at the Comprehensive Nuclear-Test-Ban Treaty (CTBT), INT'L GROUP ON GLOB. SEC., 3941 (Sep. 2008), https://www.ctbto.org/fileadmin/user_upload/pdf/External_Reports/ A_New_Look_at_the_Comprehensive_Nuclear-Test-Ban_Treaty.pdf; Des Browne, Verifying the Nuclear Test-Ban: A Regime That Works, supra note 78 (calling for designating the CTBT institutions as permanent bodies). 
provisional application can run for decades, with approximately the level of support and accomplishment as an in-force treaty. ${ }^{191}$

But that approach would still rest upon the concept of a provisional, temporary, and incomplete CTBT structure; it would not hasten the day of bringing the treaty fully into force. What the world truly needs and wants is not enhanced provisional application, but a genuine, full-fledged CTBT, and the only currently viable route to that goal is via an Implementing Agreement. There is an expressive value in the legal act of treaty-making, a worth in employing the formal trappings of international law and the hoary concept of pacta sunt servanda ${ }^{192}$ to underscore the world's opposition to nuclear testing.

In today's U.S. political environment, it is difficult to be hopeful about domestic politics supporting ratification of the CTBT any time soon, or about the United States offering meaningful leadership in moving the world toward a legally-binding, permanent test ban regime. But the rest of the world need not passively wait for political reformation in Washington, D.C. Other power centers might decide to take feasible steps toward effectuation of the CTBT, even if the global process would not come to fruition for several more years. ${ }^{193}$

The persistent blockage of CTBT is not fundamentally, and certainly not exclusively, an American problem. It was not U.S. negotiators who took the lead in crafting article XIV, and even if the United States were to ratify the treaty soon, other recalcitrant states would continue to hold up full implementation. Still, as a matter of political timing, the concept of an Implementing Agreement should be effectuated before the United States ratifies the CTBT. If the sequence were reversed-if the Senate first provided its advice and consent to the current, unmodified CTBT, and the Implementing Agreement were developed subsequently - the United States would probably not be able to take advantage of the expedited procedures contemplated here. That is, it would require bold presidential leadership, indeed, to dispense with a second vote of advice and consent. While some other countries might be empowered, under their own constitutional structures, to effectuate the Implementing Agreement without laborious

191. Bartels, supra note 189, at 112; Springer, Chapter 2, GATT 1994, available at file://C:/Users/koplow/Downloads/9783642311420-c2.pdf.

192. See VCLT, supra note 64, art. 26.

193. See Ota, supra note 58 (reporting speculation that the United States might withdraw its signature from the CTBT). 
domestic procedures, it seems likely that the U.S. Senate would insist upon having a second bite at the CTBT apple. ${ }^{194}$

That timing poses another conundrum: the rest of the world might not be willing to undertake the heavy political lifting of crafting an Implementing Agreement of this sort unless the participating states were quite confident that U.S. ratification really was forthcoming. Why undertake all these machinations if the indispensable nation might still stay on the sidelines? On the other hand, a two-thirds Senate vote of advice and consent today would accomplish only part of the job-without the streamlining provided by the Implementing Agreement, even U.S. ratification would not effectuate the CTBT.

Two scenarios might appear here. In one, many of the CTBT signatories promptly pursue the Implementing Agreement as a route to legally effectuating the test ban, even while the United States (and perhaps other leading military powers) remain missing in action. In the other, the United States is among those countries out in front pulling, despite some renegades (including some Annex 2 states) hanging back. Domestic political circumstances will likely determine which scenario is more plausible; they may eventually get to the same outcome - but the progress would be faster and smoother in the latter case.

The rest of the world sometimes does proceed with major arms control initiatives without the concurrence or even the participation of the United States (and of other prominent global security actors). The 1997 Ottawa Convention on Anti-Personnel Land Mines ${ }^{195}$ and the 2008 Oslo Convention on Cluster Munitions ${ }^{196}$ were each crafted and promoted by like-minded states which urgently sought universal affiliation with the new regimes. But those leaders were willing to proceed even without some of the world's

194. For comparison, the United States signed the LoSC Implementing Agreement subject to ratification in the ordinary way. In contrast, some states deliberately wanted to avoid having to return to their domestic authorities for a second ratification approval, and favored the simpler, easier, expedited process. Commentary-The 1982 United Nations Convention on the Law of the Sea and the Agreement on Implementation of Part XI, reprinted in UNITED NATIONS CONVENTION ON THE LAW OF THE SEA, WITH ANNEXES, AND THE AGREEMENT RELATING TO THE IMPLEMENTATION OF PART XI OF THE UNITED Nations Convention on the LAW of the SEA, With ANNEX 76, 103D CongreSS, 2D SESS., S. TREATY Doc. 103-39, (1994); Brown, supra note 134, at 7.

195. Ottawa Convention, supra note 88 . The treaty has 162 parties, not including major land mine possessing countries China, India, Pakistan, Russia and the United States. INT'L CAMPAIGN TO BAN LANDMINES-CluSTER Munition COAL. (ICBL-CMC), LANDMINE MONITOR 2016 x, 1, 17 (Nov. 2016), http://www.the-monitor.org/media/2386748/Landmine-Monitor-2016-web.pdf.

196. Convention on Cluster Munitions, Dec. 3, 2008, 2688 U.N.T.S. 39, http://www.clusterconvention.org/files/2011/01/Convention-ENG.pdf (entered into force Aug. 1, 2010). The treaty has 119 parties, not including major cluster munition possessing countries China, Russia, and the United States. ICBL-CMC, CLUSTER Munition MONitor 2016 viii, 1, 32 (Aug. 2016), http://www.the-monitor.org/media/2394895/Cluster-Munition-Monitor-2016-Web.pdf. 
major military powers, such as the United States, Russia, and China, which have not signed either instrument. The activists sought to align their own weapons postures with their own vision of security and humanity, even if doing so created persistently asymmetric legal obligations. ${ }^{197}$

Most pointedly, in 2016, the United Nations authorized the initiation of negotiations on a treaty to abolish all nuclear weapons - even though the five permanent members of the Security Council unanimously disparaged the effort and vowed not to participate. ${ }^{198}$ In short order, a Ban Treaty was concluded, with 122 states endorsing the text, despite the absence of all the countries acknowledged to possess nuclear weapons. The overwhelming majority of states were so committed to the goal of "getting to zero" nuclear weapons that they plunged ahead to sign the treaty themselves, even while other critically important players continued to resist. ${ }^{199}$ Perhaps a similar sentiment could energize momentum toward a CTBT Implementing Agreement even if some of the key forty-four states remain aloof. ${ }^{200}$

197. LANDMINE MONITOR, supra note 195, at 7-17; CLUSTER MUNITION MONITOR, supra note 196, at $7-12$

198. U.N. Gen. Assembly, First Comm. on Disarmament \& Int'1 Sec., Taking Forward Multilateral Nuclear Disarmament Negotiations, U.N. Doc A/C.1/71/L.41 (Oct. 27, 2016); G.A. Res. 71/258 (Dec. 23, 2016); Kingston Reif, UN Approves Start of Nuclear Ban Talks, ARMS ConTrOL TODAY, Nov. 2016, at 25 (reporting a vote of 123-38, with 16 abstentions, in favor of prompt initiation of negotiations, despite vigorous lobbying against the resolution by China, France, Russia, the United Kingdom, and the United States); Paul Meyer, The Nuclear Nonproliferation Treaty: Fin de Regime?, 47 ARMS CONTROL TODAY No. 3, (Apr. 16, 2017); Robert Wood, U.S. Permanent Representative to the Conference on Disarmament, Remarks at U.N. General Assembly First Committee Thematic Discussion on Nuclear Weapons (Oct. 18, 2016) https://geneva.usmission.gov/2016/10/18/ambassador-wood-remarks-at-u-n-general-assemblyfirst-committee-thematic-discussion-on-nuclear-weapons/ (expressing official U.S. opposition to the resolution); Proposed Nuclear Weapons Convention (NWC), NUCLEAR THREAT INST. (Oct. 31, 2016), http://www.nti.org/learn/treaties-and-regimes/proposed-nuclear-weapons-convention-nwc/.

199. Treaty on the Prohibition of Nuclear Weapons, [signed September 20, 2017], available at https://treaties.un.org/doc/Treaties/2017/07/20170707\%2003-42\%20PM/Ch_XXVI_9.pdf; Matthew Bolton, A Brief Guide to the New Nuclear Weapons Ban Treaty, Just Security, July 14, 2017, available at https://www.justsecurity.org/43004/guide-nuclear-weapons-ban-treaty/; John Burroughs, Key Issues in Negotiations for a Nuclear Weapons Prohibition Treaty, 47 ARMS CONTROL TODAY No. 5, 6 (June 2017) available at https://www.armscontrol.org/act/2017-06/features/key-issues-negotiations-nuclearweapons-prohibition-treaty; Briefing on Nuclear Ban Treaty by NSC Senior Director Christopher Ford, Carnegie Endowment, August 22, 2017, available at http://carnegieendowment.org/2017/08/22/briefingon-nuclear-ban-treaty-by-nsc-senior-director-christopher-ford-event-

5675?mkt_tok=eyJpIjoiWXpZeU9UUX1OV1F5TnpCaiIsInQiOiJXWXVnVjRxUTZHRHJ3RCtKWGk 2dHZLbnpvcFRJaW54TkFmUUlxUFZFSENaRW1LSTU3b1ZiZVlaYW1LMkpZZkhqN3ZGNzd0N3 M0RExDaGFMeUdHOEpZdWErWFN0b3VINkRXbT16MGITZCtadVJnMVwvNkNTdVFTZDMyVn M0UWV0c1IifQ\%3D\%3D.

200. It may be debatable how valuable an arms control agreement can be, if the key players (the states that most possess and use the weapon in question) remain outside the regime. Observers would differ, for example, regarding the direct strategic or tactical significance of the Ottawa and Oslo agreements. For the CTBT Implementing Agreement to have more than symbolic value, it would have to sooner or later attract the participation of the leading nuclear weapons possessing states. 
The process of developing, propagating, and securing international assent to the concept of a CTBT Implementing Agreement would doubtless take some time (although the 1994 experience with the comparable Law of the Sea Convention bargaining demonstrates that the mechanism can be expedited dramatically, if the international political stars align). Even if the Trump Administration proves to be no friend of the CTBT, four years could be put to good purpose by advancing the ultimate entry into force of the treaty through disposing of the artificial impediment of article XIV. International experience has amply demonstrated that even very important treaties can function for sustained periods without the participation of seemingly crucial states, such as the LoSC (lacking the United States), the LTBT (without France and China), and the NPT (absent India, Israel, North Korea, and Pakistan). ${ }^{201}$

Most importantly, the proposal here will succeed in returning the CTBT into the realm of "normal" international treaty politics. Instead of handing to the most recalcitrant states an immovable veto over the national security policies of all other countries, the Implementing Agreement creates room for more traditional, and perhaps more effective, diplomacy. Certainly, the entire world will continue to be very interested in bringing India, Iran, North Korea, Pakistan, and other outliers into the CTBT fold - the calculations that animated the original article XIV have not dissipated. But instead of relying exclusively upon the tactic of a rigid unanimity requirement, the modified CTBT could be more capacious, opening multiple, more flexible avenues of persuasion and politics.

That is, after all, the way the grand game of international security policy has been played for decades. The NPT and the LTBT, to cite just two conspicuous illustrations, have flourished even while failing to achieve $100 \%$ universality. There are two unarguable propositions here: the world would be better off if the NPT (and the LTBT) were joined by all states, instead of by nearly all; and the world is better off for having the NPT (and the LTBT) in force, rather than allowing them to linger indefinitely on the doorstep of legal operation, pending the endorsement by the last holdout state.

The chess match of international politics in treaty adherence can be quite complex and uncertain. Perhaps the dynamic will spin in a negative

201. This point reveals another partial contrast between the LoSC precedent and the CTBT Implementing Agreement. In the LoSC case, the purpose of the exercise was to facilitate the process of bringing into the regime the United States and other key developed countries, because the contemplated regime could not be effective without their participation. In the CTBT case, the objective is to allow a coalition of the willing to proceed without some of the states (potentially including the United States) that had previously been identified as essential. 
direction, with state $\mathrm{A}$ declining to join until state $\mathrm{B}$ joins, and $\mathrm{B}$ insisting upon waiting for state $\mathrm{C}$, and so forth. Sometimes, however, the flow can be positive, with $\mathrm{A}$ and $\mathrm{B}$ together pressuring $\mathrm{C}$, or $\mathrm{D}$ and $\mathrm{E}$ agreeing to make a "package deal" with F, where the value of one state accepting the treaty is amplified by its cascading effect on others.

As John R. Redick has argued in the case of the Treaty of Tlatelolco, there is real value in a multilateral standard-setting agreement, even if it lacks the participation by certain "core" countries for years or decades. ${ }^{202}$ He notes that the Latin American Nuclear Weapon Free Zone "existed for twenty-five years without the full participation of several nations [Argentina, Brazil, Chile, and Cuba] which, by any calculation (size, GNP, population, nuclear development) are key regional nations." ${ }^{203}$ Yet, the treaty helped define the regional norm of nuclear weapons prohibition, promoted the view that nonparticipating states were acting at variance with the common will of their neighbors, and led, over time, to universal acceptance of the goals.

As a domestic matter within the United States, it is possible that the Senate, in considering the CTBT and Implementing Agreement, could condition its advice and consent upon an insistence that the president not deposit the instrument of ratification (thereby bringing the treaty into force for the United States) until country X or Y (or X and Y) did likewise. That gamesmanship might handicap (or, conversely, might further empower) the executive branch in undertaking the subsequent bargaining with $\mathrm{X}$ and $\mathrm{Y}$. But at least the conditions would be written into the internal rules of the United States, subject to subsequent reevaluation and revision, as the domestic and international politics continue to writhe, rather than being cast into the un-amendable stone of the treaty text. The United States will surely want North Korea to join the CTBT, but experience has revealed the folly of ceding to Pyongyang an absolute veto over the treaty's entry into force for the United States and other like-minded countries. ${ }^{204}$

In this sense, a major treaty, as Edward Corwin famously observed about the U.S. Constitution, is "an "invitation to struggle" over foreign

202. John R. Redick, Precedents and Legacies: Tlatelolco's Contribution to the 21st Century, in NUCLEAR-WEAPON-FrEE ZONES IN THE $21^{\text {ST }}$ CENTURY, U.N. INSTITUTE FOR DiSARMAMENT RESEARCH, UNIDIR 97/37 39, 41-42 (Pericles G. Alves \& Daiana B. Cipollone eds., 1997).

203. Id. at 41 .

204. It must be conceded that this proposal does, unfortunately, relax some of the erstwhile political pressure upon the outlier Annex 2 states; activists could no longer argue to them that their participation is essential and that they are responsible for blocking the world's interest in implementing the CTBT. On the other hand, that pressure has proven unavailing for two decades, and it would now be useful to reduce the "price" that an Annex 2 state could demand in return for joining. 
policy. ${ }^{205}$ There can be no guarantee that this ceaseless struggle will lead to results that are wise, successful, or timely, but the current article XIV prevents states from approaching the enterprise with the full panoply of political strategies and inducements.

Even entry into force does not terminate that struggle. If the CTBT were to prove imperfect in operation, it would then be subject to the operation of its "normal" amendment procedures. Additionally, if the straightjacket of a non-testing regime proved too tight, a state could exercise the "supreme interests withdrawal" clause ${ }^{206}$ and exit. But again, the unorthodox route of an Implementing Agreement at least succeeds in opening up that realm of possible state practice, negotiation and experience - it re-introduces an array of national security policy tools that is currently foreclosed.

A final cautionary note: there is plenty of adverse precedent here, and many routes by which a treaty can fail. Some important arms control treaties never enter into force, despite seemingly widespread support. ${ }^{207}$ Some treaties do achieve operational status, but years or decades elapse before the United States joins. ${ }^{208}$ And some treaties do take effect, but never enjoy the participation of crucial states, dooming them to failure. ${ }^{209}$ Even with the most creative thinking and persistent efforts, the CTBT may add to those sad sagas.

The Law of the Sea Convention experience with an Implementing Agreement is instructive, if far from perfect. After all, even with the stark re-drafting of the original Part XI - as the world acceded to the U.S. interest in thoroughly revising the international rules for mining of the deep sea bed - the United States has still not joined the treaty. LoSC therefore

205. Raffaella Baritono, An Invitation to Struggle? Congress and U.S. Foreign Policy, ISPI Analysis No. 229, (Jan. 2014), http://www.ispionline.it/sites/default/files/pubblicazioni/analysis_229_2013.pdf.

206. CTBT, supra note 1, art. IX.2 (providing that each party, in the exercise of its national sovereignty, has "the right to withdraw from this Treaty if it decides that extraordinary events related to the subject matter of this Treaty have jeopardized its supreme interests").

207. Ban Ki-Moon, U.N. Secretary Gen., Secretary-General's Remarks at the Eighth Conference on Facilitating the Entry into Force of the Comprehensive Nuclear-Test-Ban Treaty (Sep. 27, 2013), https://www.un.org/sg/en/content/sg/statement/2013-09-27/secretary-generals-remarks-eighth-

conference-facilitating-entry (citing examples of the 1919 Convention for the Control of the Trade in Arms and Ammunition and the 1925 Convention for the Supervision of the International Trade in Arms and Ammunition and in Implements of War, which never entered into force).

208. Protocol for the Prohibition of the Use in War of Asphyxiating, Poisonous or Other Gases, and of Bacteriological Methods of Warfare (Geneva Protocol), June 17, 1925, 26 U.S.T. 571 (entered into force Feb. 8, 1928) (prohibiting chemical and biological warfare, but the United States did not join until Apr. 10, 1975); see GRAHAM \& LAVERA, supra note 12, at 7-10.

209. Treaty of Peace between the Allied and Associated Powers and Germany (Treaty of Versailles), at 119, June 28, 1919, 1 L.N.T.S. 403, https://www.loc.gov/law/help/us-treaties/bevans/must000002-0043.pdf (United States not a party). 
provides only a limited "success story" in the process of treaty modification - it is the treaty lawyer's version of the sad medical conclusion that "the operation was a success, but the patient died." The world will surely hesitate before once again moving a mountain to accommodate U.S. interests and demands, without adequate assurance that reciprocal performance will be forthcoming. But the LoSC case study at least validates the legal and practical availability of this contrivance.

An Implementing Agreement is, at best, a cumbersome and ungainly option. The world should not pursue it, if there were other, more feasible routes to effectuation of the CTBT. But in the absence of ratification by all forty-four Annex 2 states, and in view of the critical importance of effectuating this long-sought prize in arms control, perhaps we can best extricate ourselves from the current stasis by adopting a slight modification of the famous Sherlock Holmes solution to a persistent riddle: When all other alternatives have been eliminated as [politically] impossible, whatever remains, however improbable, must be the truth. ${ }^{210}$

210. This aphorism appears in slightly different form in several Arthur Conan Doyle works, perhaps most famously in THE SIGN OF THE FOUR (1890), ch. 6. 